\title{
Philipp Lehmann
}

\section{Eco-Physiological Aspects of Adaptation to Seasonal Environments}

The Latitudinal Range Expansion of the Colorado Potato Beetle Across Europe

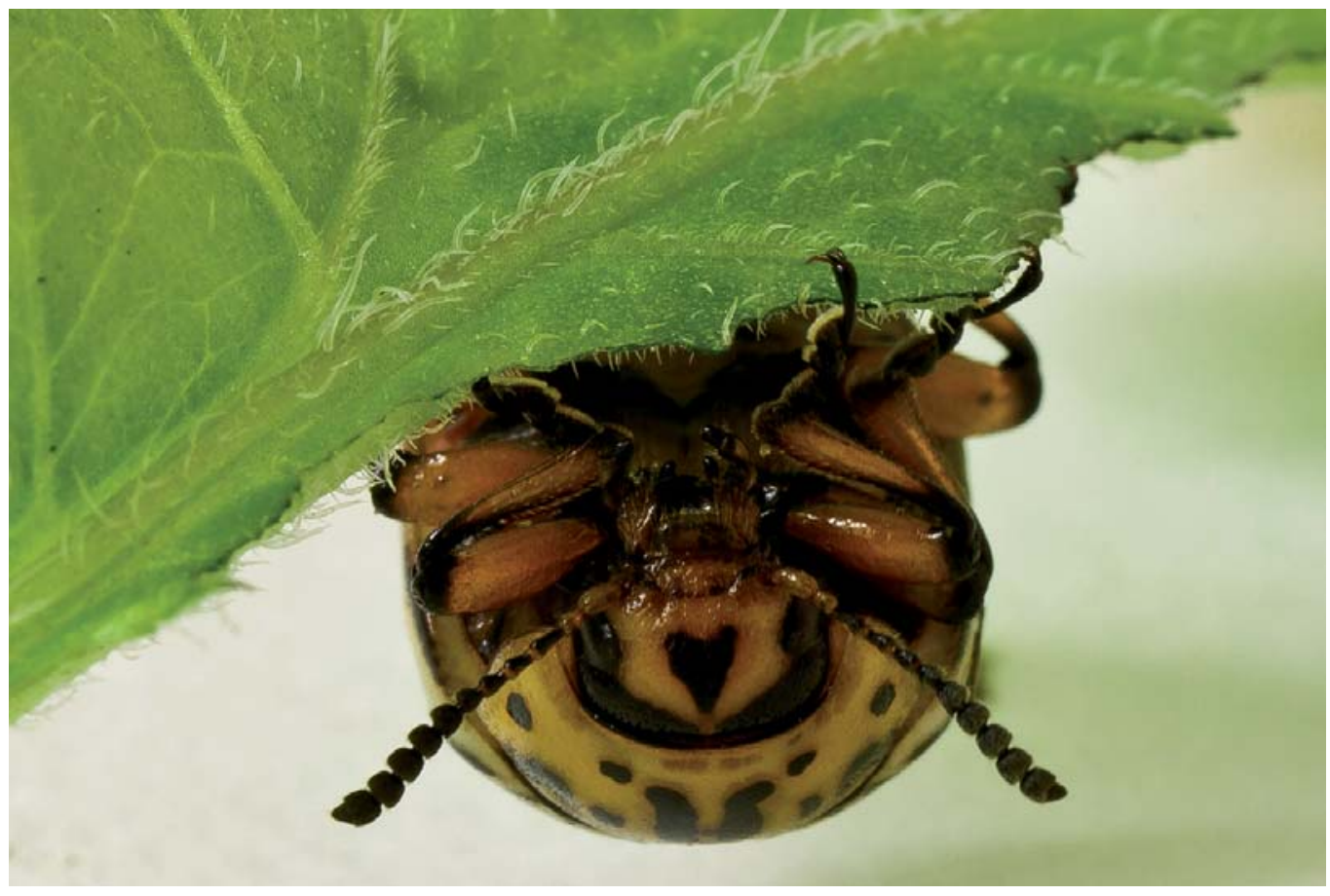




\section{Philipp Lehmann}

\section{Eco-Physiological Aspects of Adaptation to Seasonal Environments}

\section{The Latitudinal Range Expansion of the Colorado Potato Beetle across Europe}

Esitetään Jyväskylän yliopiston matemaattis-luonnontieteellisen tiedekunnan suostumuksella julkisesti tarkastettavaksi yliopiston vanhassa juhlasalissa S212 syyskuun 13. päivänä 2013 kello 12.

Academic dissertation to be publicly discussed, by permission of the Faculty of Mathematics and Science of the University of Jyväskylä, in Auditorium S212, on September 13, 2013 at 12 o' clock noon.

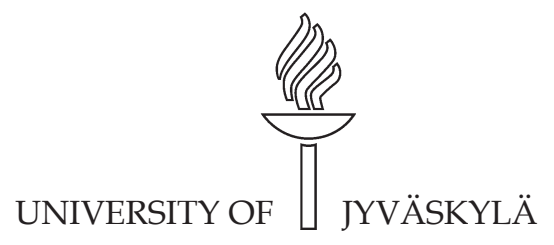

JYVÄSKYLÄ 2013 


\section{Eco-Physiological Aspects of Adaptation to Seasonal Environments}

The Latitudinal Range Expansion of the Colorado

Potato Beetle across Europe 


\section{Philipp Lehmann}

\section{Eco-Physiological Aspects of Adaptation to Seasonal Environments}

The Latitudinal Range Expansion of the Colorado Potato Beetle across Europe

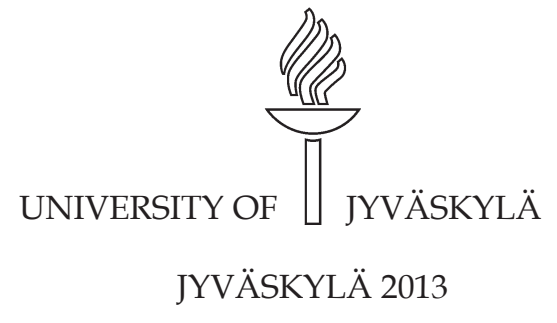


Editors

Timo Marjomäki

Department of Biological and Environmental Science, University of Jyväskylä Pekka Olsbo, Harri Hirvi

Publishing Unit, University Library of Jyväskylä

Jyväskylä Studies in Biological and Environmental Science

Editorial Board

Jari Haimi, Anssi Lensu, Timo Marjomäki, Varpu Marjomäki

Department of Biological and Environmental Science, University of Jyväskylä

Cover picture by Valtteri Jokinen

URN:ISBN:978-951-39-5364-5

ISBN 978-951-39-5364-5 (PDF)

ISBN 978-951-39-5363-8 (nid.)

ISSN 1456-9701

Copyright (C 2013, by University of Jyväskylä

Jyväskylä University Printing House, Jyväskylä 2013 


\author{
ABSTRACT \\ Lehmann, Philipp \\ Eco-physiological aspects of adaptation to seasonal environments: the \\ latitudinal range expansion of the Colorado potato beetle across Europe \\ Jyväskylä: University of Jyväskylä, 2013, 73 p. \\ (Jyväskylä Studies in Biological and Environmental Science \\ ISSN 1456-9701; 265) \\ ISBN 978-951-39-5363-8 (nid.) \\ ISBN 978-951-39-5364-5 (PDF) \\ Yhteenveto: Ekofysiologisia sopeumia vuodenaikaisvaihteluun: \\ Koloradonkuoriaisen leviäminen Euroopassa \\ Diss.
}

Successful range expansion in seasonal environments requires that organism's phenology is synchronized with novel season length. Therefore during invasion events or climate change, novel photoperiodic synchronization can be required for persistence as many organisms use the photoperiod to cue seasonal progression. The Colorado potato beetle, Leptinotarsa decemlineata, represents a species which rapidly has spread across latitudes and thus has been under selection by changes in photoperiod. In the present thesis I study whether European L. decemlineata show latitudinal patterns in life-history and physiological traits which would indicate adaptation to local season length and thermal environment. Beetles from 4 populations of approximately known age, were originally collected along a latitudinal axis and reared in common garden laboratory environments. I investigated variation in life-history and physiological traits important in phenological synchronization and diapause. My results show that critical photoperiod for diapause induction follows a robust latitudinal pattern and suggests rapid divergence. Pre-diapause development is associated with large physiological changes, such as storage lipid accumulation and increased expression of stress tolerance related genes. Northern populations have an accelerated pre-diapause developmental ontogeny when compared to southern populations. This is also supported by signs of compensatory growth. Since the latitudinal population dependent differences in critical photoperiod (and other life-history and physiological traits) show strong synchronization with local season length, the capacity of rapid life-history adaptation has probably been an important reason for the range expansion success of this invasive species. However, stress related behavior in very long photoperiods and weak cold-tolerance related trait expression during the pre-diapause period suggests that further northwards range expansion might be constrained.

Keywords: Local adaptation; phenology; phenotypic plasticity; rapid adaptation. 
Author's address

Supervisors

Reviewers

Opponent
Philipp Lehmann

Department of Biological and Environmental Science

P.O. Box 35

40014 University of Jyväskylä

Finland

philipp.lehmann@jyu.fi

Docent Leena Lindström

Department of Biological and Environmental Science

P.O. Box 35

40014 University of Jyväskylä

Finland

Docent Anne Lyytinen

Department of Biological and Environmental Science

P.O. Box 35

40014 University of Jyväskylä

Finland

Professor Thomas Flatt

Department of Ecology and Evolution

University of Lausanne

Switzerland

Docent Karl Gotthard

Department of Zoology

University of Stockholm

Sweden

Associate Professor Daniel Hahn

Department of Entomology and Nematology

University of Florida

United States 


\title{
CONTENTS
}

\author{
ABSTRACT \\ CONTENTS \\ LIST OF ORIGINAL PUBLICATIONS \\ ABBREVIATIONS
}

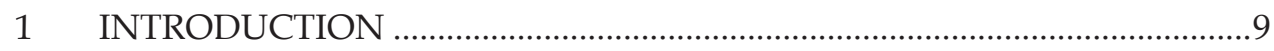

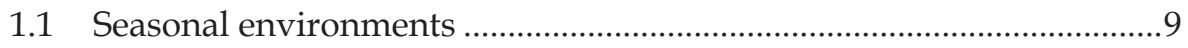

1.2 Latitudinal patterns in life-history traits in seasonal environments.......10

1.3 Survival during a harsh winter.............................................................13

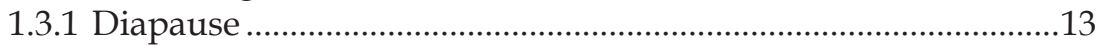

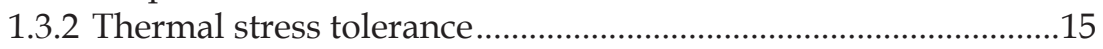

1.4 Phenological synchronization and the photoperiodic calendar ..........16

1.5 The endocrinological control of diapause ..............................................17

1.6 Biological invasions: natural laboratories of range expansion and

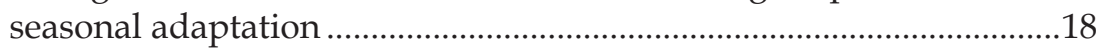

1.7 The invasion biology of Leptinotarsa decemlineata...................................19

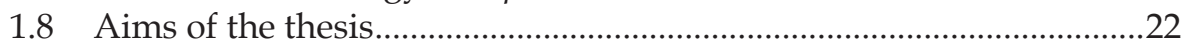

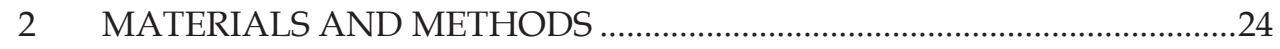

2.1 Study animals and general rearing conditions.....................................24

2.2 Life-history and behavioural traits (Studies I, II, IV, V) .......................27

2.2.1 Development time and adult mass gain .......................................27

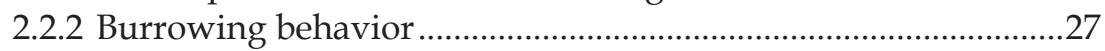

2.3 Lipid and water content measurements (Studies II, III, V) .................27

2.3.1 Total lipid and water content measurements ..............................27

2.3.2 Lipid fractioning method ...............................................................28

2.3.3 Comparison of two lipid extraction methods ................................29

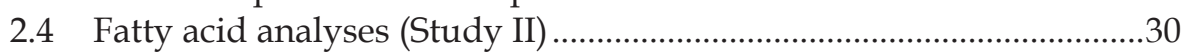

2.5 Quantitative real-time PCR (Study III) ....................................................31

2.6 Hormone analogue topical applications (Study IV) ................................32

2.7 Metabolic rate measurements (Study V) .................................................33

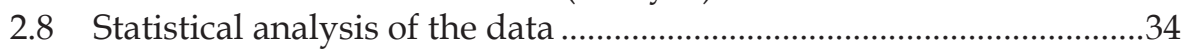

2.8.1 Analyses of quantitative traits..........................................................34

2.8.2 Analysis of fatty acid profiles (Study II) …………….....................34

2.8.3 Analysis of gene expression (Study III) ............................................35

2.8.4 Analysis of resting metabolic rate (Study V)..................................35

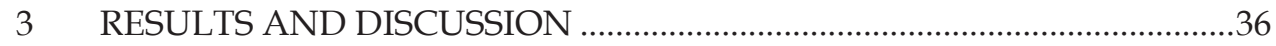

3.1 Patterns in growth related traits, critical photoperiod and diapause incidence suggest adaptation to local season length ..............................36

3.2 Diapause preparation is associated with neutral lipid sequestering, but not with homeoviscous adaptation or metabolic suppression ....39 
3.2.1 Energy store sequestering: total lipids ..........................................39

3.2.2 Homeoviscous adaptation: Fatty acid profiles ..............................40

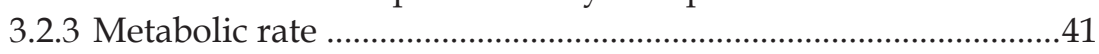

3.3 Ontogenic patterns in expression of diapause related genes support that adaptation to northern conditions has occurred ...............................4

3.4 Life-history adaptation has probably not proceeded through change in the endocrinological machinery .............................................................4

3.5 Varying degrees of behavioral plasticity in burrowing could indicate erosion of plasticity due to harsher winters .............................4 44

4 CONCLUSIONS AND FUTURE DIRECTIONS .........................................4

Acknowledgements .................................................................................................51

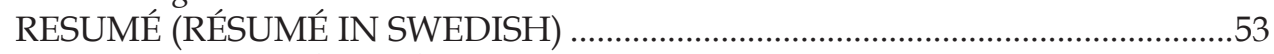

YHTEENVETO (RÉSUMÉ IN FINNISH) …………............................................57

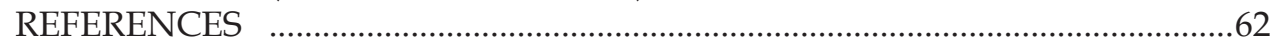




\section{LIST OF ORIGINAL PUBLICATIONS}

The following five original papers, referred to by roman numerals I-V, form the framework of the current thesis.

I Lehmann, P., Lyytinen, A., Piiroinen, S. \& Lindström, L. Rapid adaptation to seasonality: Latitudinal differentiation in critical photoperiod for diapause and life-history traits in European Colorado potato beetles (Leptinotarsa decemlineata). Manuscript.

II Lehmann, P., Lyytinen, A., Sinisalo, T. \& Lindström, L. 2012. Population dependent effects of photoperiod on diapause related physiological traits in an invasive beetle (Leptinotarsa decemlineata). Journal of Insect Physiology, 58: 1146-1158.

III Lehmann, P., Piiroinen, S., Kankare, M., Lyytinen, A., Paljakka, M., \& Lindström, L. Differential expression of diapause-associated genes in European Leptinotarsa decemlineata populations: rapid latitudinal range expansion driven by photoperiodic adaptation. Manuscript.

IV Lehmann, P., Lyytinen, A., Piiroinen, S. \& Lindström, L. Mechanisms of photoperiodic adaptation at high latitudes: the role of the endocrinological machinery in driving local adaptation in the Colorado potato beetle. Manuscript.

V Lehmann, P., Lyytinen, A., Piiroinen, S. \& Lindström, L. Northward range expansion requires synchronization of both physiology and overwintering behavior with photoperiod in the invasive Colorado potato beetle Leptinotarsa decemlineata. Manuscript.

This table shows major contributions to the individual manuscripts.

\begin{tabular}{llllll}
\hline \hline Study & I & II & III & IV & V \\
\hline Original idea & PL & LL, AL & PL, SP, AL, & PL, LL & PL, AL, \\
$\begin{array}{l}\text { Experimental design } \\
\text { and work }\end{array}$ & PL, SP, & PL, AL, & PL, SP, MP, & PL, SP, LL & PL, AL, \\
Data analysis & AL, LL & TS, LL & AL, LL & SL \\
& PL, AL, & PL, AL, & PL, SP, MK & PL, AL, SP, & PL, AL, \\
Writing of the & SP, LL & TS, LL & & SP, LL \\
manuscript & PL, AL, & PL, AL, & PL, SP, MK, & PL, AL, SP, & PL, AL, \\
& SP, LL & TS, LL & AL, MP, LL & LL & SP, LL \\
\hline
\end{tabular}

PL = Philipp Lehmann, LL = Leena Lindström, AL = Anne Lyytinen, SP = Saija Piiroinen, TS $=$ Tuula Sinisalo, MP = Marjut Paljakka, MK = Maaria Kankare 


\section{ABBREVIATIONS}

$\begin{array}{ll}\text { CA } & \text { Corpora allata } \\ \text { CPP } & \text { Critical photoperiod } \\ \text { DE } & \text { Diethylether } \\ \text { FAME } & \text { Fatty acid methylester } \\ \text { GC-MS } & \text { Gas chromatography - mass spectrometry } \\ \text { HSP } & \text { Heat shock protein } \\ \text { JH } & \text { Juvenile hormone III } \\ \text { JHE } & \text { Juvenile hormone esterase } \\ \text { JHEH } & \text { Juvenile hormone epoxide hydrolase } \\ \text { LD } & \text { Long day }(18 \text { h light }: 6 \text { h dark }) \\ \text { NLFA } & \text { Neutral lipid fatty acid } \\ \text { PLFA } & \text { Phospholipid fatty acid } \\ \text { PTTH } & \text { Prothoracicotropic hormone } \\ \text { RMR } & \text { Resting metabolic rate } \\ \text { RT } & \text { Room temperature }\left(23{ }^{\circ} \mathrm{C}\right) \\ \text { SCP } & \text { Supercooling point } \\ \text { SD } & \text { Short day }(12 \text { h light }: 12 \mathrm{~h} \text { dark }) \\ \text { UI } & \text { Unsaturation index } \\ \text { US } & \text { Unsaturation ratio }\end{array}$




\section{INTRODUCTION}

\subsection{Seasonal environments}

During a fine July day at Medicine Lake in Montana $\left(46^{\circ} \mathrm{N}\right)$, the air temperature of $48^{\circ} \mathrm{C}$ was measured. On January the $20^{\text {th }}$, relatively close by, at Rogers Pass, the air temperature of $-57^{\circ} \mathrm{C}$ was measured. This extreme $105^{\circ} \mathrm{C}$ temperature difference at two locations, separated only by a few hundred kilometers, and a few months, is one example of the range of seasonal environmental variation present in large biogeographic ranges. For indeed, most non-tropical environments show seasonal changes in abiotic factors, such as temperature, radiation, wind, salinity and humidity (Willmer et al. 2000). These abiotic factors affect primary producers, which in turn set in motion some of the largest biological energetic cycles on Earth, for example marine algal blooms, seasonal cycles of photosynthesis in the taiga, and the re-growth of annual weeds in savannah (Reece et al. 2011). These, and other, annual growth cycles in turn affect herbivores and their predators and parasites, which also show seasonality in many traits.

Through seasonal, or phenological, synchronization, animals optimize ontogenic development and reproduction with favorable ambient conditions. Some extreme examples of behavioral seasonal traits include the migratory behavior of 1300000 Wildebeest (Chonnochaetes sp.) in Africa (Thirgood et al. 2004) or the $71000 \mathrm{~km}$ migration of the arctic tern (Sterna paradisae) (Egevang et al. 2010), where resource rich habitats are tracked. An extreme example of ontogenic phenological synchronization is the mass emergence of the 13- or 17year cicada (Magicidada sp.), by which reproductive success is increased due to lessened relative predation and parasitism pressure (Cox \& Carlton 1988, Goles et al. 2001). Another example of seasonal adaptations is the inducible extreme cold tolerance of some arctic insects, able to survive when body temperature decreases to as low as $-60{ }^{\circ} \mathrm{C}$ (Somme 1999, Worland et al. 2000).

While the majority of species living in seasonally changing environments might not show as extreme adaptations as described above, they nevertheless 
often have adapted on both behavioral, physiological and biochemical levels to survive the rigors of seasonally varying environments. One important adaptation is the photoperiodic timing of reproduction or development of stress resistant resting stages (Nelson et al. 2010, Denlinger \& Lee 2010). Furthermore, since seasonality in itself varies in space (e.g. with latitude) and time (e.g. as a result of climate change), animals often need to re-synchronize their phenology according to novel seasonality (Tauber et al. 1986, Gaston 2003, Bradshaw \& Holzapfel 2007). There are many factors by which seasonal environments at high latitude influence the life-cycle and stress tolerance of animals. Of these, four major factors are: the length of the growth season when ontogenic development and reproduction are favorable, the length of the harsh part of the season when development and reproduction are unfavorable, the ambient temperature throughout the year and the magnitude of short term variation in temperature (Roff 1983, Willmer et al. 2000, Denlinger \& Lee 2010).

\subsection{Latitudinal patterns in life-history traits in seasonal environments}

Many abiotic environmental factors vary in a clinal manner with latitude, including temperature and photoperiod (day length). Together with ambient humidity, they are the main factors determining the length of the optimal photosynthetic growth season, which is negatively correlated with latitude (going north or south from the equator) (e.g. Gaston 2003). The length of the plant growth season, as well as temperature, affects the developmental window of most animals, and thus requires that life-history and phenological stress tolerance related traits of animals are well synchronized with the seasonality of the local environment. Therefore animals with large geographic ranges or insects which are undergoing range expansion have to locally adapt to varying summer environments, which can be seen as adaptive clines in life-history and stress tolerance related traits (Roff 1983, 1992).

Life-history traits represent integrated systems of major traits with large effects on the fecundity and fitness of an organism. Some well-studied lifehistory traits are: size at birth, growth pattern, age and size at sexual maturity, number, size and sex ratio of offspring, age- and size-specific reproductive investments, age- and size-specific mortality schedules and length of life (Stearns 1992). Since these traits are integrated, multilevel systems, with polygenic quantitative genetic backgrounds and whose expression often is plastic, the study of mechanism is challenging (Flatt \& Heyland 2011). Studies aiming to elucidate the genetic, molecular or physiological mechanisms behind patterns of evolution in life-history traits therefore often focus on more specific traits or components of life-history traits (Roff 1992, Zera 2007, Flatt \& Heyland 2011). 
Evolution of life-history trait shifts is expected and necessary for survival at high latitude (Roff 1980, 1983). Commonly, the age of reproduction, developmental time, growth rate, body size and timing of overwintering are connected to latitude in a population or species specific manner as a response to selection by abiotic factors (Roff 1983, Tauber et al. 1986, Bradshaw \& Holzapfel 2007). For example, latitudinal clines in adult body size in ectotherms have been proposed to be correlated with the temperature and length of the available favorable growth season. Positive and negative, as well as neutral clines in body size have been described. Bergmann's rule, originally explaining mammalian patterns, states that adult body size increases with latitude (Bergmann 1847). Even though there is some empirical evidence for Bergmann's rule also in ectotherms, the mechanisms are not fully understood and debated (e.g. van Voorhies 1996, Mousseau 1997, Blanckenhorn \& Demont 2004, Kivelä et al. 2011). The trend is partly accredited to the so-called temperature-size rule, which states that ectotherms grow larger at lower temperatures (von Bertalanffy 1960, Atkinson \& Sibly 1997, Chown and Gaston 1999, Angiletta et al. 2004). The opposite trend, where adult body size decreases with increasing latitude is called the converse Bergmann's rule, and has received significant both theoretical and empirical support (e.g. Mousseau 1997, Chown \& Gaston 1999, Blanckenhorn \& Demont 2004). The converse Bergmann's rule has in ectotherms often a strong genetic component (contrary to the temperature mediated temperature-size rule), and suggests that selection by short growth season has favored reaching reproductive maturity with small adult body size, thereby speeding up the life-cycle by decreasing the time needed for development (Blanckenhorn \& Demont 2004). The third major hypothesis explaining latitudinal variation in adult body size is through countergradient variation (also known as the latitudinal compensation mechanism) and relates to variation in development rate. By accelerating development rate in populations at high latitude or altitudes (Chown \& Klok 2003), adult size remains constant when compared to populations at lower latitude or altitude (Blanckenhorn \& Demont 2004).

In addition to body size and development time, latitudinal clines in size are further complicated by trends in growth rate or mass gain within developmental stages. For instance, species which overwinter in a resting stage or which migrate often need to attain a critical weight to survive, since mass gain in the developmental stage preparing for winter is generally positively correlated with energy store build-up (Hahn \& Denlinger 2007). In these species, individuals from populations at high latitude are expected to show an increased rate of weight gain compared to lower latitude populations, to compensate for the shorter time available for preparation. As noted by several authors, there are inherent physiological interdependencies between growth rate, development time and adult weight gain, and therefore care must be taken when analyzing them in isolation (Blanckenhorn \& Demont 2004, Kivelä et al. 2009, Nijhout et al. 2010, Kivelä et al. 2011).

Several physiological traits have been implicated as being of particular importance in determining the success of insects during the benign period of 
the year at high latitude. Most of these relate to functional aspects of life-history variation of development time, adult size and mass gain, and include for instance metabolic or energy conversion rates (e.g. Chown \& Gaston 1999). Positive or negative latitudinal patterns in resting metabolic rate (RMR) have been observed in a range of ectotherm species. Positive clines are often gathered under the umbrella term "metabolic cold adaptation" (e.g. Chown \& Gaston 1999, Addo-Bediako et al. 2002, but see Hodkinson 2003 and Lardies et al. 2004) where a short growth season is suggested to select for higher metabolic rate assuming that high RMR leads to improved foraging efficiency (e.g. Terblanche \& Anderson 2010), energy conversion (e.g. Chown \& Nicholson 2004) and increased growth rate (Chown \& Gaston 1999, Blanckenhorn \& Demont 2004, Lyytinen et al. 2008, Dmitriew 2011, Kivelä et al. 2011). Thus development and preparation for reproduction, migration or overwintering is possible in a short time window (Blanckenhorn \& Demont 2004, Chown \& Nicholson 2004, Piiroinen et al. 2011). Some studies propose a latitudinal gradient of selection for lower metabolic rate instead of higher (discussed above) which relates to the transfer of limited resources from maintenance to somatic growth (Clarke 1993, Chown and Gaston 1999). However, as stated by several authors, latitudinal general trends in metabolic rate (i.e. elevated versus suppressed) might offer a too simplistic picture of a complex physiological system, which for instance might vary with development stage or age (Clarke 1993, Chown \& Gaston 1999, Hodkinson 2003, Lardies et al. 2004).

Latitudinal life-history trait patterns can be further complicated by within season variation in abiotic traits, such as temperature. Average ambient temperature is generally negatively correlated with latitude (e.g. Gaston 2003) and perhaps more importantly, also the magnitude of seasonal fluctuations in temperature correlates with latitude, in general becoming larger with increasing latitude (Tauber et al. 1986). Low temperature or large fluctuations in temperature are among the most important direct stressor of biological systems (Willmer et al. 2000, Denlinger \& Lee 2010). Furthermore, as described above, growth and development rates are often directly affected by ambient temperature, especially in ectotherm animals (Randall et al. 2002). Therefore it is not surprising that ectotherms have developed many ways of avoiding stress inducing temperatures, or tolerating temperature related stress, especially in environments with large annual fluctuations in temperature (Addo-Bediako et al. 2000, Denlinger \& Lee 2010). During the growth season, daily fluctuations in temperature are often countered by behavioral adaptations (such as burrowing into the soil), generally higher stress tolerance compared to lower latitude/altitude populations, or the capacity of rapid cold hardening (Salt 1961, Somme 1999, Addo-Bediako et al. 2000). Thermal tolerance limits have often been accredited to be a major factor in determining absolute range limits for ectotherm species (e.g. Addo-Bediako et al. 2002). These direct stress related adaptations are however of secondary importance compared to the optimal timing of development and reproduction and indeed even at arctic latitudes a short part of the summer is in general benign enough to support ontogenic development (Roff 1983, Addo-Bediako et al. 2000, Gaston 2003). 


\subsection{Survival during a harsh winter}

\subsubsection{Diapause}

In most temperate seasonal environments, part of the year is too harsh to support ontogenic and reproductive development (Willmer et al. 2000). In these environments animals employ other strategies than short term behavioral avoidance or generally increased stress tolerance (discussed above). These strategies can be grouped into two main categories: spatial avoidance (migration) and temporal avoidance. The decision to migrate or overwinter usually means forfeiting a reproductive opportunity. Indeed, since most animals only reproduce during one season, correct timing of their single reproductive period is crucial (e.g. Klowden 2007). There exists a trade-off between reproducing during summer or the following spring, if reproduction increases overwintering mortality of adults (Murdoch 1966, Roff 1983, 1992). Additionally, if mortality faced by offspring developing late in summer is high (due to time constraints or abiotic stress), it might be beneficial for adults postpone reproduction and overwinter in spite of mortality associated with winter (Roff 1983, Tauber et al. 1986).These decisions play a major role in phenological synchronization and have been studied in many systems during the last century (Murdoch 1966, Tauber et al 1986). In ectotherms, the most common form of temporal avoidance is the development of resting stages (Denlinger \& Lee 2010). The main reason is probably that migration, at the scale required for avoidance of adverse winter conditions, is energetically unfeasible for small ectotherms. However, also ectotherms overwintering in resting stages very often show spatial avoidance on a small scale, and overwinter in sheltered microclimates (Leather et al. 1993).

A common way by which ectotherms and insects in particular survive harsh winter conditions is to enter diapause. Unlike more shallow dormancies, usually collectively called quiescence, which are direct results of non-cyclic deviations from normal weather conditions, and often are directly reversible upon the resumption of benign conditions, diapause is seen as the most elaborate, complex and highly evolved overwintering state (reviewed in e.g. Tauber et al. 1986, Danks 1987, Leather et al. 1993, Kostal 2006). Diapause is a neurohormonally mediated, genetically determined set of physiological events that occurs during a species specific stage of the life cycle, and can be either obligatory or facultative (Tauber et al. 1986). Obligatory diapause is most common in species which diapause during the egg or larval stage of univoltine species, and means that diapause is initiated as part of the developmental program during a specific time point regardless of the current environmental conditions. Facultative diapause is most common in multivoltine species (i.e. species with more than one annual generation) and species where the adults enter diapause, and requires that individuals need to make a decision to initiate diapause. This decision is usually the integrated response to several environmental cues, such as photoperiod, temperature, food availability and humidity (Danilevski 1965, Tauber et al. 1986). Adult diapause is 
usually characterized by reproductive arrest, suppressed metabolism and high tolerance to many environmental stressors, such as low temperatures, desiccation, and increased risk of infections (Danks 1987, MacRae 2010). Variation in the intensity and mode of diapause is very large (Tauber et al. 1986, Saunders 2002, Hahn \& Denlinger 2007). For instance, while some insects do not eat and remain completely immobile during diapause, others can forage and move about, although often at a strongly reduced rate, when compared to non-diapausing counterparts (Leather et al. 1993, Hahn \& Denlinger 2007). Indeed, the notion of diapause as a complete temporal removal of the organism for a period of time is no longer appreciated; instead diapause is seen as a dynamic period of stress-related survival, managing of resources and sometimes even somatic development (Kostal 2006, Hahn \& Denlinger 2007, 2011).

Diapause related overwintering behavior can be surprisingly straightforward, or intriguingly complex. Representing the straightforward side, many temperate Lepidoptera overwinter as pupae, and thus overwinter where the larvae chose to form the pupae, locations which often are very exposed (such as a tree trunk) (Leather et al. 1993, Willmer et al. 2000). However, within taxon variation is large and another butterfly, the Monarch butterfly, Danaus plexippus, represents a complex strategy (Brower et al. 1977). Adult Monarch butterflies migrate from relatively high latitudes in southern Canada southwards in huge numbers, to overwinter in refugia in Mexico or California. Interestingly, where the travel south is completed in a single generation, the migration northwards is an annual expansion which encompasses up to four generations (Brower et al. 1977). However, even though migration is common in temperate overwintering ectotherms, it is usually on a much smaller spatial scale, where animals seek out suitable microhabitats for overwintering (Leather et al. 1993). Abiotic conditions can change dramatically depending on microhabitat and therefore many arthropods seek sheltered refugia where they overwinter, such as under snow, bark or burrowed into the soil. Indeed, burrowing $10 \mathrm{~cm}$ into the soil has been calculated to reflect top-soil temperatures at $1000 \mathrm{~km}$ lower latitude (Willmer et al. 2000). For instance European corn borer larvae, Pyrausta nubialis, overwinters within the food substrate, corn stalks (Beck \& Hanec 1960), queens of the bumblebee Bombus terrestris, dig small overwintering burrows in north facing slopes (Beekman 1998) while young adults of the cave spider Meta menardi seek out suitable overwintering caves (Fritzén \& Koponen 2011).

Individuals preparing for diapause also need to prepare for a long period without energy income (Danks 1987). Even though metabolic demands are suppressed, basic somatic upkeep and expression of diapause related genes, such as for instance stress tolerance proteins, are required for survival (Grodzicki \& Walentynowicz 2011). Therefore insects which diapause as adults typically prepare for overwintering by building large lipid stores in a special organ called the fat body (Hahn \& Denlinger 2011). Energy can also be stored in other biochemical forms, for instance as carbohydrates and proteins, but since the energy yield per unit weight in carbohydrates and proteins is much lower than in lipids, lipids are the most common form (Arrese \& Soulages 2010). 
Stored lipids are not only essential for survival during diapause in many species, but also for post-diapause fitness (Hahn \& Denlinger 2007) where they act as energy starting capital for, among other, dispersal and development of reproductive tissues (Lefevere et al. 1989, de Kort 1990). In the fat body, most hemolymph lipids garnered from the breakdown of food are converted into neutral lipids (triglycerides or triacylglycerides) (Arrese \& Soulages 2010). Neutral lipids are the main form of storage lipids in the insect fat body, usually constituting more than $90 \%$ of the fat body total lipid mass (Canavoso et al. 2001). It is of importance to note that also reproductively active individuals gather lipids, which are used for oogenesis and to fuel mating behavior, and that these lipids also can be in the form of neutral lipids stored in the fat body (de Loof \& Lagasse 1970).

\subsubsection{Thermal stress tolerance}

During winter ectotherms often face high levels of abiotic stress, of which thermal stress associated with low temperatures (together with desiccation) is the most severe (Danks 2007, Denlinger \& Lee 2010). Insects have two main cold tolerance strategies to cope with subzero temperatures. Some insects, often living in arctic environments, are freeze tolerant, and can survive the formation of internal ice. These usually try to actively form ice during the early stages of diapause at relatively high temperatures $\left(-4{ }^{\circ} \mathrm{C}\right.$ to $\left.-10{ }^{\circ} \mathrm{C}\right)$, through the production of ice-nucleating agents which assist in the controlled freezing of the inter-cellular space (Salt 1961, Somme 1999). Ironically, most studies on insect cold tolerance have focused on extreme environments, and therefore much more is known about the minority of insects which are freeze-tolerant than about the cold tolerance of non-arctic insects, which make up the bulk of species (Block 1990). For most non-arctic insects are freeze intolerant and cannot survive the formation of ice crystals within their bodies, and strive to minimize the chances of internal ice formation through various biochemical, physiological and behavioral means (Salt 1961, Bale \& Hayward 2010). These include the production of so called "anti-freeze" substances, or cryoprotectants, often polyols or sugars such as glycerol or trehalose, which increase the osmolarity of the intra- and intercellular fluids, thus decreasing the freezing point, below a summer average, and often well below zero (Salt 1961). Thus decreased, the fluids are termed supercooled, and the supercooling point is a major physiological characteristic measured from a wealth of ectotherms (e.g. Zachariassen et al. 2008). Another important physiological strategy, in addition to the production of cryoprotectants, is the active dehydration of internal compartments and voiding of the gut to clear out potential ice nucleators (Somme 1999, Danks 2007). Dehydration increases osmolarity, and together with the active discharge of nucleators through gut voiding, freezing risk is decreased, even though dehydration also carries trade-offs, since dehydration in itself is linked to mortality (Danks 2007). Indeed, the more uncommon strategy of freeze-tolerance has been suggested to carry as an additional benefit the saving of internal water (Leather et al. 1993, Danks 2007). 
Even though risk of freezing is minimized through various means, tissues, membranes, proteins and enzymes often need additional protection to uphold functionality at low temperatures. Therefore several biochemical and physiological adaptations which relate directly to functionality are present in overwintering ectotherms (e.g. Denlinger \& Lee 2010). These include a large swathe of molecular rearrangements of fatty acids, both neutral lipids and phospholipids (reviewed by Kostal 2010). Typical changes include for instance: a decrease in fatty acid average length, an increase in fatty acid average degree of unsaturation, changes in the location of double bonds, changes in the head group composition (of phospholipids) (Hochachka \& Somero 2002). These changes are necessary to uphold membrane functionality at low temperatures (phospholipids), and also to allow access to lipid stores for energetic purposes (neutral lipids) (Sinensky 1974, Hazel 1995, Kostal \& Simek 1998, Hodkova et al. 2002). The mechanism is usually referred to as homeoviscous adaptation. Another typical feature of diapausing insects is the chronic and inducible upregulation of heat shock protein (HSP) expression (Yocum 2001, Denlinger 2002, MacRae 2010). Heat shock proteins are molecular chaperones which assist in regulating the functionality of proteins during times of cellular stress (low/high $\mathrm{pH}$ or temperature for instance) (Lindquist 1986, Goto and Kimura 1998, Feder \& Hoffmann 1999, Hochachka \& Somero 2002). During diapause, several different heat shock proteins have been found to be up-regulated for long periods, in some cases the whole overwintering period (Denlinger 2002, Rinehart et al. 2007, MacRae 2010). Also other stress related proteins, such as desiccation proteins have been found to be up-regulated during diapause (Graham et al. 1996, Yocum 2003, Yocum et al. 2011).

Also increases in ambient temperature can be stressful (Denlinger \& Lee 2010). A particularly large risk for overwintering insects are heat shocks during the end of the overwintering period. Increased ambient temperature can terminate diapause, which can have deleterious consequences, especially through depletion of energy stores before the winder ends (Hahn \& Denlinger 2007). However, also direct thermal stress can affect organisms negatively, even though buffered in the overwintering state (Willmer et al. 2000). Therefore it is not surprising that many of the mechanisms described above, such as HSP production, also buffers against sudden increases in temperature (Lindquist 1986, Hochachka \& Somero 2002, MacRae 2010).

\subsection{Phenological synchronization and the photoperiodic calendar}

During seasonal transitions many animals use the photoperiod to time their life-cycle (reviewed by Bradshaw \& Holzapfel 2007, Nelson et al. 2010). This is because photoperiod is an inter-annually reliable indicator of time of year (Bradshaw \& Holzapfel 2007) and thus allows organisms to predict coming seasonal shifts much more accurately than when using more variable signals which often also directly affect organism performance (such as temperature or 
food availability). This has led to various adaptations to the photoperiod in lifehistory, behavioral and physiological traits, such as the timing of migration, development or reproduction, initiation of overwintering and seasonal patterns of stress tolerance (e.g. Saunders 2002, Kawecki \& Ebert 2004, Nelson et al. 2010, Flatt \& Heyland 2011).

The photoperiod is measured by an elaborate neuro-molecular system often called the photoperiodic calendar (Kostal 2011). The function of the photoperiodic calendar is probably linked to the function of the daily photoperiodic rhythm sensing circadian clock, a theory postulated 80 years ago by Erwin Bünning (1936), and strengthened through several decades of intense research (Saunders 2002, Nelson et al. 2010, Kostal 2011). While the interplay of the same molecular mechanisms in the circadian and seasonal photoperiod sensing systems remain a matter of great debate (e.g. Bradshaw \& Holzapfel 2007), the photoperiodic requirements of organisms to make phenological decisions is much better known (e.g. Saunders 2002, Nelson et al. 2010). Most animals track not only the absolute length of the day, but also require a certain amount of days in a row with a photoperiod of over or under a certain threshold to trigger a phenological decision (e.g. Danilevski 1965, Nelson et al. 2010, Kostal 2011). While there are some examples of rapid photoperiodic adaptation (e.g. Bradshaw \& Holzapfel 2001, Gomi 2007, Dalin et al. 2010, Urbanski et al. 2012), the actual molecular and physiological mechanisms of photoperiodic adaptation are still largely unclear (Bradshaw \& Holzapfel 2007, Kostal 2011). There is a demand for more research in this area since it is becoming increasingly clear that photoperiodic adaptation is an important driver during range expansion since it allows species to re-synchronize lifehistory and stress tolerance related traits with novel phenology (Tauber et al. 1986, Nelson et al. 2010). Also, as a consequence of climate change, the capacity of many organisms, including pests and disease vectors, to expand their range in a warmer world may critically depend on their capacity to shift photoperiodic induction of life-history switches (Bradshaw \& Holzapfel 2010, Saikkonen et al. 2012).

\subsection{The endocrinological control of diapause}

Phenological shifts, including overwintering, are often hormonally driven (Gilbert et al. 2012). The encocrinological control of diapause initiation and development has been intensely studied in several species during the last 80 years, and shows substantial variation depending on which life-stage that overwinters (Nijhout 1994, Gilbert et al. 2012). Embryonic diapause in for instance Bombyx mori is under maternal control through a so called diapause hormone, while larval diapause in Chilo suppressalis or pupal diapause in Manduca sexta is the result of inhibition of prothoracicotropic hormone (PTTH) and ecdysteroid secretion (Nijhout 1994, Gilbert et al. 2012). In insects which overwinter as adults, diapause is generally associated with low titers of Juvenile 
Hormone III $(\mathrm{JH})$, a sesquentoterpenoid produced in a paired organ in the back of the insect brain, called the corpora allata (CA) (de Kort et al. 1982, Gilbert et al. 2012). The hemolymph titer of the hormone is regulated by the interplay of biosynthesis and enzymatic degradation by JH-esterases (JHE) (Nijhout 1994, Vermunt et al. 1999). Biosynthesis is regulated by yet another group of hormones called allatotropins (up-regulate biosynthesis) and allatostatins (down-regulate biosynthesis) (Khan et al. 1988, Nijhout 1994). Additionally, a group of hormones called ecdysteroids are implicated in the formation of the diapause phenotype, at least in some species, although the exact roles are still somewhat unclear (Denlinger 2002). What is quite clear nevertheless, is that diapause involves many physiological pathways and consists of several distinct processes that need regulating, and that hormones are likely to play key roles in several of them (de Kort 1990, Gilbert et al. 2012).

\subsection{Biological invasions: natural laboratories of range expansion and seasonal adaptation}

Species ranges are living, moving things, and the integrated response to the capacity of species to cope with various outer stressors (Gaston 2003). Often the range limit of a species is an abiotic barrier (e.g. mountain chain, ocean, upper or lower lethal temperature limit), but can also be biotic, such as the range of a host plant, prey animal or competing species. Individuals tend to continuously diffuse across range limits, but seldom show large jumps across barriers, although this can and does happen, such as North American birds flying to Europe, or whales navigating into the Baltic Sea. These mistakes are often isolated cases with fatal consequences for the individuals. Human activity, most notably over-sea traffic and active introductions is increasingly allowing species to spread far beyond their ranges, over and beyond geographic obstacles, by introducing them to a novel environment (Elton 1958, Sax et al. 2005). Even though introductions are fairly common, only a small fraction of species successfully establish themselves in the novel environment (Williamsson \& Fitter 1996, Jeschke \& Strayer 2006). However, species which do succeed in their invasion often display remarkable growth and expansion (Sakai et al. 2001). There are several postulated reasons for this. One relates to the species showing some important pre-adaptation in life-history or stress tolerance traits (Thebaud et al. 1996, Reichard \& Hamilton 1997, Kolar and Lodge 2001, Sakai et al. 2001), for instance due to adaptations to large seasonal disturbances in their native range (Winkler et al. 2008). Another reason is high evolvability or plasticity in life-history or stress tolerance traits (Lee and Petersen 2003, Lee et al. 2003). Yet another reason is lack of parasites or predators in the invaded environment (Sax et al. 2005). Alternatively, already disturbed habitats with low species number might hold open ecological niches, where invasive species face scarce competition (see Elton 1958, Sax et al. 2005). Since many invasive species have 
negative impact on the invaded habitat, there is often a direct applied value for understanding the evolutionary ecological dynamics of species persistence and spread probability in the novel habitat (Elton 1958, Sakai et al. 2001). However, studies on organisms which are in the process of rapidly expanding their range can provide valuable information on the evolutionary ecological mechanisms of range expansion (Yoshida et al. 2007, Fauverge et al. 2012) since they represent species rapidly expanding their range margin into novel selection pressures, for instance along a latitudinal axis (Elton 1958, Gaston 2003).

\subsection{The invasion biology of Leptinotarsa decemlineata}

The study species in my thesis is the Colorado potato beetle, Leptinotarsa decemlineata, discovered and named by Thomas Say (Say 1824). The then described leaf beetle was just one of a group of 30 odd closely related chrysomelids living in rather low density populations in Central America and the southwestern part of USA. This changed dramatically when potato, Solanum tuberosum, was introduced into the southern states of the USA as a crop between 1840 and 1850. Soon afterwards some of the native L. decemlineata shifted host plants from the local potato relative, Buffalo bur, Solanum rostratum, to potato and became invasive. To quote Tower (1906): "The advent of this new food, however, completely removed the expansion barrier, and there lay open to the eastward an expanse of territory where optimum conditions of existence were developed." Indeed, the common name, Colorado potato beetle, stems from the first American state where a major outbreak occurred (Casagrande 1987). Today L. decemlineata is the worldwide most important insect pest of potato found in an area covering 16 million $\mathrm{km}^{2}$ which stretches from Mexico, through North America, to most of Europe and deep into Asia (Johnson 1967, Alyokhin 2009, EPPO 2006). The invasion has been rapid, since the first major outbreak happened as recently as around 150 years ago (Casagrande 1987, Alyokhin 2009). Indeed, annual expansion distance has been estimated to be between 80 - $130 \mathrm{~km}$ in North America and Europe (Walsh 1865, Riley 1877, Tower 1906, Johnson 1967, EPPO 2006).

$L$. decemlineata is a holometabolous oligophagous herbivore which overwinters in diapause. New adults emerging from pupae during the summer decide whether they will reproduce, migrate or overwinter depending on environmental cues, most notably the photoperiod (de Wilde et al. 1959). Reproductive maturity is reached within one week after eclosion, after which adults mate and females lay eggs, in batches of up to 100 eggs on the underside of potato leaves. Males display mate guarding, and females often mate with multiple males (Alyokhin 2009). Single females have impressive fecundity, and can lay up to 1000 eggs in their life-time. The development of eggs to larvae takes between 4 and 6 days, and larvae undergo 4 instars, which all feed on potato, and develop into adults in 30 days at optimal conditions $\left(23^{\circ} \mathrm{C}\right)$, although this time can be significantly increased at lower temperatures, i.e. 60 
days at $15{ }^{\circ} \mathrm{C}$ (Logan et al. 1985, Lyytinen et al. 2009). Adult beetles show so called spring dispersal, and especially males often take to flight after emerging from overwintering burrows (Alyokhin \& Ferro 1999). Flight mode and distance is also strongly temperature dependent (Alyokhin \& Ferro 1999). Since L. decemlineata is a major pest of potato, controlling population densities with pesticides has been forcefully employed throughout its range. The species is very capable of resisting pesticides (probably partly due to the natural toxicity of the alkaloids of the host plant, potato), and also rapidly evolving new resistance against new pesticides (Alyokhin 2009). Indeed, L. decemlineata is justifiably called a super-pest due to the many features (fecundity, dispersal, pesticide resistance) which have allowed the fast expansion across the northern hemisphere (Hsiao 1985, Alyokhin 2009).

One important feature which has allowed L. decemlineata to spread from its almost sub-tropical native range to the almost sub-arctic northern range margin in Europe (EPPO 2006) is the capacity of adults to burrow into the soil for diapause (e.g. Hsiao 1985). Prolific research done in the former USSR, the Netherlands and North America during the latter half of the $20^{\text {th }}$ century has established the basic framework of diapause induction in this species (Danilevski 1965, Tauber et al. 1986, de Kort 1990). Diapause is driven by short photoperiods experienced by the adult beetles shortly after eclosion (de Wilde et al. 1959) although it is positively influenced by low temperature and shortage of food (de Kort 1990). There is population dependent variation in critical photoperiod (CPP) (when $50 \%$ of mature adults initiate diapause), but evidence for the extent of photoperiodic adaptation is not conclusive (de Wilde et al. 1959, Danilevski 1965, Tauber et al. 1988). Adult beetles destined for diapause normally migrate to the sides of potato fields, or into neighboring forest patches, where they burrow into the soil, to depths between 20 and $80 \mathrm{~cm}$ (Lefevere \& de Kort 1989, Milner et al. 1992). Thus burrowed they can remain from 6 to 9 months. Pre-diapause is accompanied by low JH hemolymph titers and high JHE expression (Figure 1) (de Kort 1990, Vermunt et al. 1999). At the end of the overwintering period, beetles become sensitive to soil temperature, and terminate diapause and emerge when temperatures rise above $10^{\circ} \mathrm{C}$ (Alyokhin 2009). Diapause normally lasts one winter season, but can also be prolonged and last up to 9 years (Tauber and Tauber 2002). Another interesting characteristic is the large variation of diapause responses found on the population level; where around $20 \%$ of newly eclosed adults in all thus far studied populations enter diapause regardless of environmental conditions (Danilevski 1965, Hsiao 1985, Tauber et al. 1986, de Kort 1990). The mechanisms and possible environmental triggers behind prolonged and obligate diapause (i.e. the $20 \%$ which enter regardless of photoperiod) and whether there is a genetic component driving them are not clear. What the origin of diapause in this species is can be debated, since winter is comparatively mild in Mexico, and seasonal photoperiodic fluctuations close to the equator are minimal (Nelson et al. 2010). Indeed, L. decemlineata is generally reproductively active throughout the year in Mexico (Hsiao 1985). It is possible that diapause is part of an evolutionarily conserved resting program, which might have arisen when ancestral species occupied ranges at higher latitude (Bradshaw \& Holzapfel 2010). 
Physiological regulation of $\mathrm{JH}$ titer

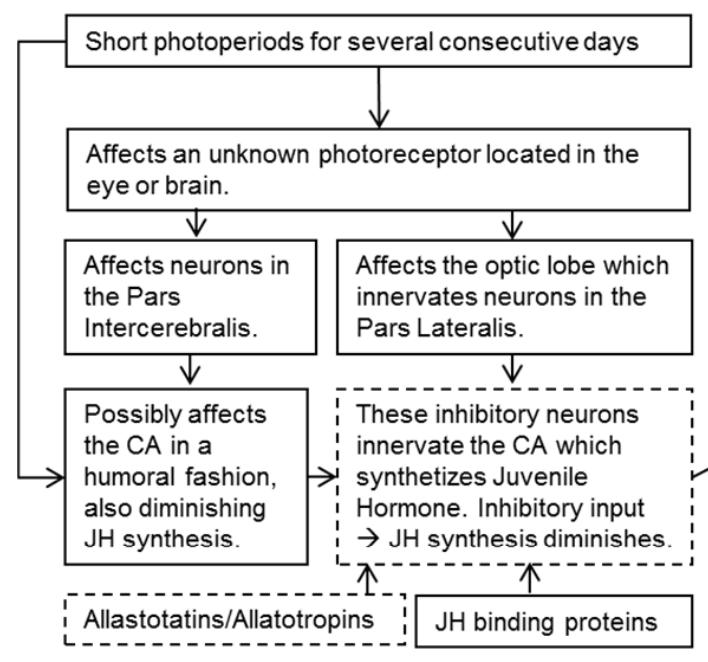

Increased expression rate of JHE in the fat body.

Increased expression rate of JHE in the fat body. 1

Increased expression rates of JHEH in target tissues.

JHE expression diminishes at around 8-10 days, when $\mathrm{JH}$ titer nears 0 .

Modulation of diapause induction by temperature humidity, population density or food quality.

(1)

\section{Pre-diapause development}

JH titer Days post eclosion

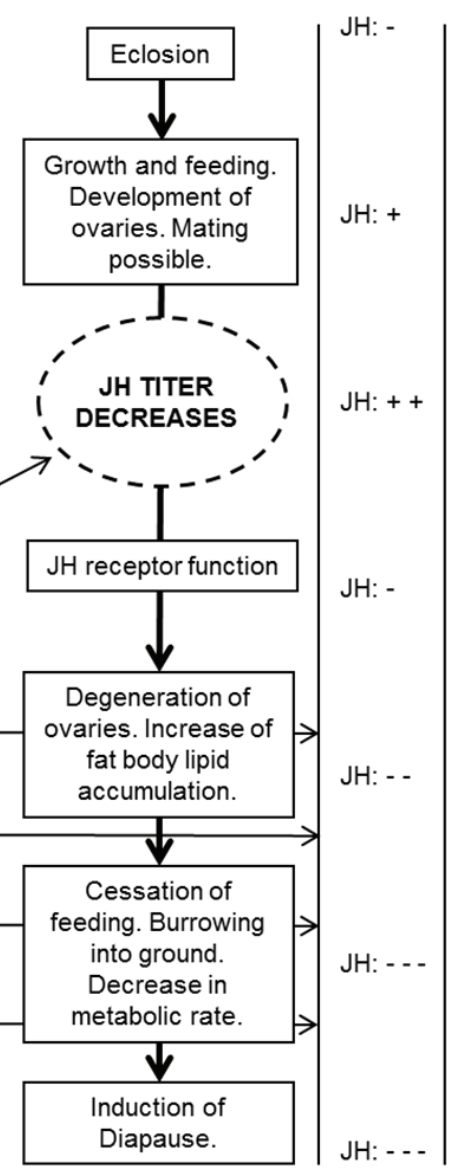

1

2

4

6

FIGURE 1 A model of the main endocrinological drivers of pre-diapause development in adult female L. decemlineata reared under diapause inducing conditions. Pre-diapause development is fairly similar in most insects overwintering as adults studied so far. Boxes surrounded by broken lines contain functions which were investigated in this thesis. Days are approximations based on averages reported in several studies. JH titer variation is large, and only the general direction reported. It should be stressed that many parts of the regulatory machinery are still very vaguely known, and inter-species variation is large. For instance, the cellular JH receptor still remains unknown and the link between $\mathrm{JH}$ titer and Insulin signaling has only been investigated in a handful of studies (Tatar et al. 2001, Williams et al. 2006, Sim and Denlinger 2008). Therefore many steps are to be taken as hypothetical. JH: Juvenile Hormone III, JHE: Juvenile Hormone Esterase, JHEH: Juvenile Hormone Epoxide Hydrolase, CA: Corpora Allata. The figure is based on references: Tauber et al. 1986, Khan et al. 1988, de Kort 1990, Nijhout 1994, Vermunt et al. 1999, Gilbert et al. 2012 and work cited therein. 


\subsection{Aims of the thesis}

Adaptation to high latitude requires synchronization of life-history and stress tolerance traits on several organismal levels with the seasonal changes in the environment. Most of the species and populations used to study photoperiodic adaptation so far have been well established and have had time to adapt to the photoperiod over many generations (Nelson et al. 2010). Less attention has been given to what is happening on the actual migration front of invasive species, and the physiological mechanisms involved in driving successful range expansion. L. decemlineata offers an opportunity to study photoperiodic adaptation from a historic as well as a contemporary, ongoing perspective. The traits studied in this thesis relate to two disparate areas of insect biology, which both are associated with survival at high latitude. The main goal of this thesis relates to the evolutionary ecology of L. decemlineata. The studies focus on traits which relate to survival during a shorter growth season and traits relating to survival of lower winter temperatures. Since experiments were conducted in split family common garden environments, I could assess the level of plasticity in the respective populations when reared under different photoperiodic regimes, as well as study whether populations have adapted to the local phenology of their environments. Since range expansion has been rapid, the results of my thesis might yield insights into the interplay between abiotic and biotic factors affecting survival at high latitude and how insects have evolved to tolerate them.

In my thesis I asked five general questions. First, since higher latitude imposes increased temporal constraints on development, I studied whether beetles collected from different latitudes differ in life-history traits such as development time, adult mass gain or fecundity profiles (study I). Second, since late summer photoperiod becomes longer with increased latitude, I studied whether beetles from higher latitude have shifted their CPP to match local phenology, i.e. CPP increasing with latitude (study I, II). Third, I studied several physiological traits associated with diapause to assess whether shifts in diapause behavior are accompanied with shifts in relevant diapause related physiological traits (study II, III and IV). Successful overwintering at high latitude requires, among other things, the attainment of lipid stores under a longer photoperiod, and possibly also in a shorter timeframe. Additionally, economic use of these reserves is vital, and suppression of metabolic functions (of which the metabolic rate is an integrated response) is considered important (Kostal 2006). Therefore I studied population dependent differences in lipid store composition and size, as well as pre-diapause RMR, to see if the higher levels of abiotic stress expected at high latitude have led to the sequestering of larger lipid stores and stronger depression of metabolic rate in northern beetles preparing for diapause (study II, III). Thermal stress tolerance was also studied in the form of fatty acid profiles and their degree of unsaturation (study II) as well as expression profiles of stress tolerance related genes in beetles preparing 
for diapause (study III). Fourth, the molecular pathway linking the tracking of photoperiodic information to downstream endocrinological effectors is largely unknown in most species. Therefore I studied population dependent differences in expression profiles of genes belonging to the circadian clock and the insulin signaling pathway (study III). Also hormones could be likely candidates in driving population dependent divergence, since they sit on key regulatory points in the pathways producing differing phenotypes (Zera 2007, Oostra et al. 2010). Additionally, I study whether there are population dependent differences in susceptibility to manipulations of hemolymph $\mathrm{JH}$ titers by manipulating them positively or negatively through topical applications (study IV). And lastly, since adult L. decemlineata can adjust the depth of their burrow during diapause (Milner et al. 1992) and are thus able to actively choose overwintering conditions which are stable and benign (Lefevere et al. 1989), a diapause related increase in cold tolerance might not have been strongly selected for during the migration northwards (see Piiroinen et al. 2011) due to behavioral plasticity (see also Lee et al. 1995). The association between several physiological traits and behavior was assessed in several studies (II, V), and additionally the burrowing depth of northern and southern beetles was studied. 


\section{MATERIALS AND METHODS}

\subsection{Study animals and general rearing conditions}

In this thesis, common garden experiments were used to study variation in lifehistory, physiological and stress tolerance related traits of L. decemlineata beetles collected along a latitudinal gradient in Europe. L. decemlineata from 4 populations were used in the studies included in this thesis. They were the descendants of beetles collected from 3-5 potato fields more than $10 \mathrm{~km}$ apart from each other, in Petroskoi (Russia), Belchow (Poland), Emmen (the Netherlands) and Padua (Italy) (Table 1). Field collected beetles were not used in any experiment, and all beetles used had undergone at least one overwintering period under laboratory conditions. Possible maternal effects from the local conditions were thus minimized (Mousseau and Dingle 1991). Overwintering mortality is in our laboratory fairly low (around $30 \%, 5$ year average across populations), which should minimize potential laboratory selection based on winter survival. The parental beetles were mated within populations under a long day photoperiod (18 h light), and their offspring reared in family groups till adulthood under short day photoperiods (12 h light) at the constant temperature of $23{ }^{\circ} \mathrm{C}$ in controlled environmental chambers (Type B1300; Weiss Technic). After eclosion, adult beetles were maintained individually on petri dishes (diameter of $9 \mathrm{~cm}$ ) containing a water moistened filter paper and fed daily with fresh potato leaves (Solanum tuberosum of the van Gogh variety). The parental beetles were overwintered at $5{ }^{\circ} \mathrm{C}$ in dark environmental chambers for 8-9 months. Overwintering was initiated with a 6 week period where temperatures gradually decreased, from 23 to 15, 10 and finally $5{ }^{\circ} \mathrm{C}$, with two week intervals. During spring, temperatures were gradually increased in a similar fashion, and overwintering jars were checked daily for emerged adults after the temperature had been increased to $23^{\circ} \mathrm{C}$.

For the experiments females and males from separate families were mated within populations after adults had emerged from overwintering diapause. Mated pairs were checked for deposited eggs daily. Larvae (10-15 per family) were reared on whole potato plants in a greenhouse till adulthood (see 
Piiroinen et al. 2011 for more detailed rearing conditions) at $23^{\circ} \mathrm{C}$ degrees, $60 \%$ relative humidity and 18 hours light. Newly eclosed adults were weighed $( \pm 0.1$ mg, AM100; Mettler) on the day of emergence. Based on emergence weight new adult beetles were divided into treatment groups by making sure each family was represented in each treatment group and the emergence weights were similar among groups. In all but one experiment (study I) the adults were reared in two photoperiods; long day (LD): 16 hours full light, 6 of darkness with two 1-hour low-light periods imitating dawn and dusk (18 h light); and short day (SD): 10 hours full light, 12 hours dark with two 1 hour low-light period imitating dawn and dusk (12 h light) (Figure 2). In study I, 6 photoperiods were used: 24:0 (light:dark), 21:3, 18:6, 15:9, 12:12 and 9:15. No dawn or dusk period was used.

In studies II, III and V I analyzed beetles at three ages: at adult emergence (day 0 ), when 5 days old and when 10 days old. At around 10 days after adult emergence L. decemlineata are physiologically ready for diapause (de Wilde et al. 1959, Piiroinen et al. 2011) and therefore differences between photoperiods and populations should be manifested at this age. Additionally, in several studies a subsample of beetles was allowed to overwinter. These were either taken for analyzes during diapause (after 170 days in diapause, study II) or allowed to overwinter (study I and IV). Beetles destined for diapause were weighed when 6 (study I and V) or 10 days old (study II) $( \pm 0.1 \mathrm{mg}$, AM100; Mettler) and moved to plastic jars (volume $80 \mathrm{ml}$ ) containing peat. The jars had hard plaster on the bottom to allow for moistening of the peat and holes in the lid for oxygenation of the peat. The beetles were fed with fresh potato leaves daily and the time of digging into the peat was monitored. Two weeks after placing beetles into peat jars they were moved to a 24-hour dark environmental chamber at $15^{\circ} \mathrm{C}$, two weeks after that to a 24 hour dark chamber at $10^{\circ} \mathrm{C}$ and finally to a 24-hour dark chamber at $5{ }^{\circ} \mathrm{C}$. This gradual decrease in temperature was needed to allow the beetles to acclimatize to the low overwintering temperature and was chosen to reflect field conditions. Beetles in the field dig to depths of between 20 and $40 \mathrm{~cm}$ where temperatures generally are above $0{ }^{\circ} \mathrm{C}$ (Lefevere \& de Kort 1989, Milner et al. 1992). In the southern part of Finland (62 ${ }^{\circ} \mathrm{N}$ ), the average winter soil temperature at a depth of $50 \mathrm{~cm}$ is $3.2^{\circ} \mathrm{C}$ (range $0.1^{\circ} \mathrm{C}$ to $13^{\circ} \mathrm{C}$ ) between September and May (Heikinheimo \& Fougstedt 1992).

TABLE 1 Coordinates and average growing conditions at the locations where beetles were collected for this study.

\begin{tabular}{llllll}
\hline \hline Origin & Coordinates & Fields & Collection year & Temp. $\left({ }^{\circ} \mathrm{C}\right)^{*}$ & Longest day \\
\hline Petroskoi & $61^{\circ} 49^{\prime} \mathrm{N}, 34^{\circ} 10^{\prime} \mathrm{E}$ & 3 & 2006 & 13 & $19: 00$ \\
Emmen & $52^{\circ} 54^{\prime} \mathrm{N}, 06^{\circ} 51^{\prime} \mathrm{E}$ & 4 & 2011 & 15 & $16: 30$ \\
Belchow & $52^{\circ} 01^{\prime} \mathrm{N}, 20^{\circ} 34^{\prime} \mathrm{E}$ & 3 & 2010 & 15 & $16: 30$ \\
Padua & $45^{\circ} 48^{\prime} \mathrm{N}, 12^{\circ} 07^{\prime} \mathrm{E}$ & 3 & 2008,2010 & 20 & $15: 30$ \\
\hline \hline
\end{tabular}

*Average temperature from May to Sept. based on 18-50 year averages from www.weatherbase.com (accessed 6.2.2013). Closest weather stations used (Petroskoi: St. Petersburg, Emmen: Groeningen, Belchow: Lodz and Padua: Padua). 
(a)

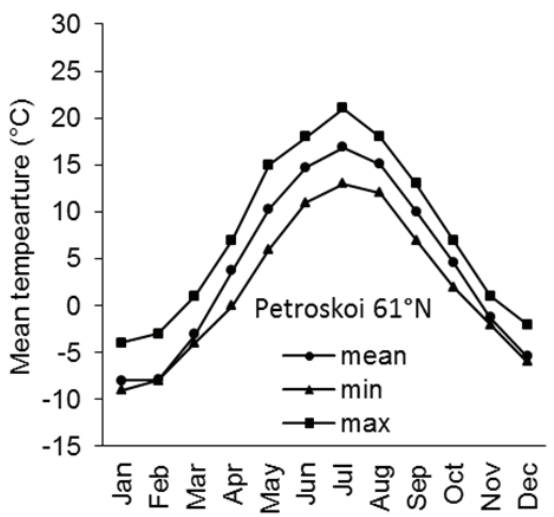

(c)

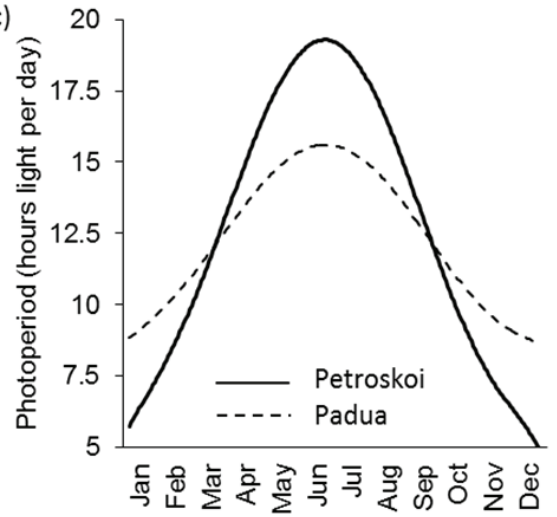

(b)

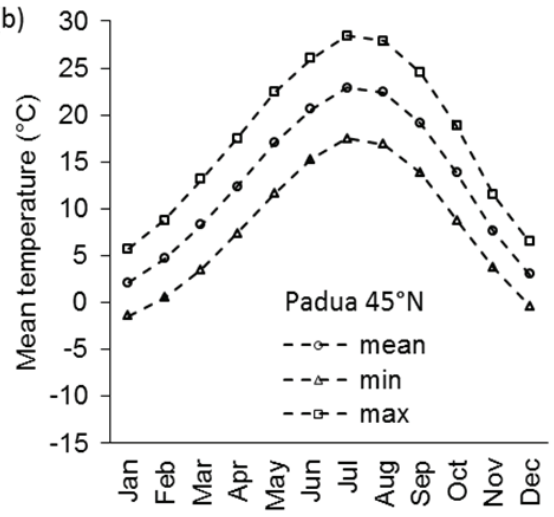

(d)

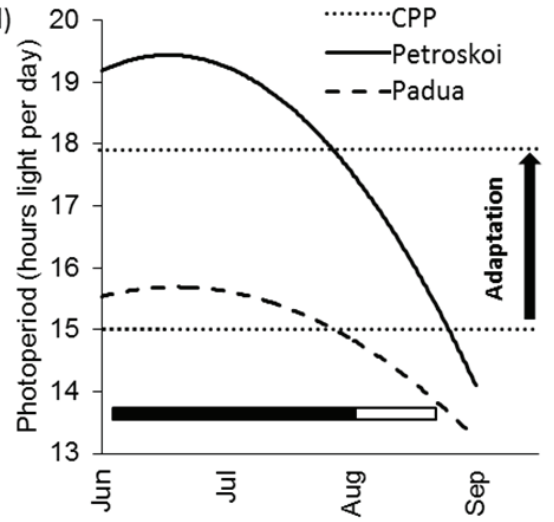

FIGURE 2 Summary of temperature and photoperiodic differences between the environments of the most northern and southern population studied in this thesis. Figure (a) and (b) show monthly mean temperatures and average minimum and maximum temperatures (over a 50 year period) of the northern (Petroskoi) and southern (Padua) locations (www.weatherbase.com, accessed 29.5.2013). Note that $y$-axis scales are the same. Figure (c) shows annual photoperiodic fluctuations at the two locations. Figure (d) shows natural photoperiods in Petroskoi and Padua. The critical photoperiod (CPP) for Colorado potato beetles from central Europe (the Netherlands) is shown as the lower dotted line (based on de Wilde 1959). The rectangle shows the approximate emergence time for the first new generation of beetles at both locations. In Padua this means that adults emerging from midsummer to the end of July face long days (solid part) after which new adults face a short photoperiod and should prepare for overwintering (open part). For beetles in Petroskoi, the critical photoperiod of $15 \mathrm{~h}$ is reached very late. The upper dashed line shows the long day photoperiod used in the experiment and the solid arrow the seasonal shift in Petroskoi which would result of photoperiodic synchronization. Figure (d) is reprinted from Lehmann et al. 2012 (study II), with permission from Elsevier. 


\subsection{Life-history and behavioural traits (Studies I, II, IV, V)}

\subsubsection{Development time and adult mass gain}

One part of the thesis was to study if latitudinally imposed constraints on growth season length have affected life-history traits related to development time and adult mass gain. Development time was measured as the amount of days needed for hatched larvae to emerge from the ground as adults. Last $\left(4^{\text {th }}\right)$ instar larvae burrow into the ground for pupation and emerge as adults. Adult mass gain is reported as proportional mass gain between adult emergence and 6 or 10 days of age.

\subsubsection{Burrowing behavior}

To investigate the burrowing response as an indication of diapause initiation, burrowing into the soil (burrowed into the soil or on the soil surface) was recorded when beetles were 10 days old and had been in the overwintering jars for three days (Tauber et al. 1988, Seyanake et al. 2000) (II, III). In an additional experiment I assessed burrowing depth of a subset of beetles from Petroskoi ( $N$ $=40)$ and Padua $(N=40)$ used in study IV. Eight plastic tubes (length $1 \mathrm{~m}$, diameter $10 \mathrm{~cm}$ ) were filled with pre-moistened soil (Figure 3D). For the experiment, 10 adult non-feeding beetles (10 - 15 days old) which were not treated with any of the substances used in the topical applications were placed in each tube (males and females from the Petroskoi and Padua population separately, in two replicates). The beetles were overwintered as described in section 2.1. The tubes were moistened once 1.5 months after reaching the final holding temperature of $5^{\circ} \mathrm{C}$ (Lefevere \& de Kort 1989, Costanzo et al. 1997) and opened 1.5 months after that. The data was analysed with a factorial general linear model with 10 day weight as covariate and replicate as random factor.

\subsection{Lipid and water content measurements (Studies II, III, V)}

\subsubsection{Total lipid and water content measurements}

To test if populations differ in the amount of energy stored in the fat body depending on photoperiod, I analyzed abdominal total lipids with gravimetric choloroform:methanol (Chl:Meth) extractions. Samples for total lipid and water content analyses were taken at the approximately same time during the synthetic photoperiod, between 2 and 4 hours after light on. Total lipid content of the abdomen was measured after extraction with Chl:Meth (Folch et al. 1957). Abdomen were and weighed (fresh weight) $( \pm 0.01 \mathrm{mg}$, AM105DU; Mettler), then placed in aluminum cups and dried for 72 hours at $55^{\circ} \mathrm{C}$. They were then reweighed (dry weight) and placed in glass vials $(20 \mathrm{ml})$ containing $10 \mathrm{ml}$ 
Chl:Meth (2:1 [vol:vol]) for 72 hours in a fume hood at room temperature (RT, $\left.23^{\circ} \mathrm{C}\right)$. Chl:Meth effectively dissolves lipids in the sample into the liquid phase. This includes neutral lipids and phospholipids, but also glycerol, carbohydrates and amino acids (Newman et al. 1972). Therefore results obtained with this method might overestimate the total lipid content (see Williams et al. 2011). Abdomen were after the Chl:Meth submersion put into aluminum cups and dried for another 72 hours at $55{ }^{\circ} \mathrm{C}$ and weighed (lean weight). Total relative water content $(\mathrm{w} / \mathrm{w})$ was calculated by subtracting dry weight from fresh weight and dividing by fresh weight. Total relative lipid content $(\mathrm{w} / \mathrm{w})$ was calculated by subtracting lean weight from dry weight and dividing by dry weight.

\subsubsection{Lipid fractioning method}

To assess the proportions of different lipid categories of the abdominal total lipids, a subset of abdomen samples in study II were fractioned. Previous studies have shown that the main portion of fat body total lipids is triacylglycerides (Canavoso et al. 2001), which are part of the neutral or simple lipids. To confirm that this is the case in L. decemlineata the abdominal total lipids were fractioned. The total abdominal lipid fraction left to dissolve for $72 \mathrm{~h}$ in $10 \mathrm{ml}$ 2:1 Chl:Meth. To control for the efficacy of the method, four vials with $1.7 \mathrm{mg}$ of the phospholipid phosphocholine (Larodan Fine Chemicals Ab) in 9 $\mathrm{ml}$ of methanol were also fractionated. All lipid fractions were dried completely under nitrogen and the lipids dissolved in $300 \mu \mathrm{CHCl} 3$ and fractioned using a Bond Elut C18 solid phase extraction column (Varian). The lipid species were eluted using a modified protocol of Blight and Dyer (1959, see Taipale et al. 2009) with the following solvents: neutral lipids with $10 \mathrm{ml}$ chloroform, glycolipids with $10 \mathrm{ml}$ acetone and phospholipids with $10 \mathrm{ml}$ methanol. The individual fractions were dried under nitrogen and dissolved in $1 \mathrm{ml}$ chloroform. Lipid content was determined gravimetrically. Two samples of 100 $\mu \mathrm{l}$ of the fraction were extracted with a Hamilton syringe and put in pre weighed tin cups, dried for $2 \mathrm{~h}$ at RT and weighed $( \pm 0.001 \mathrm{mg}, \mathrm{CP} 2 \mathrm{P}$; Sartorius).

(a)

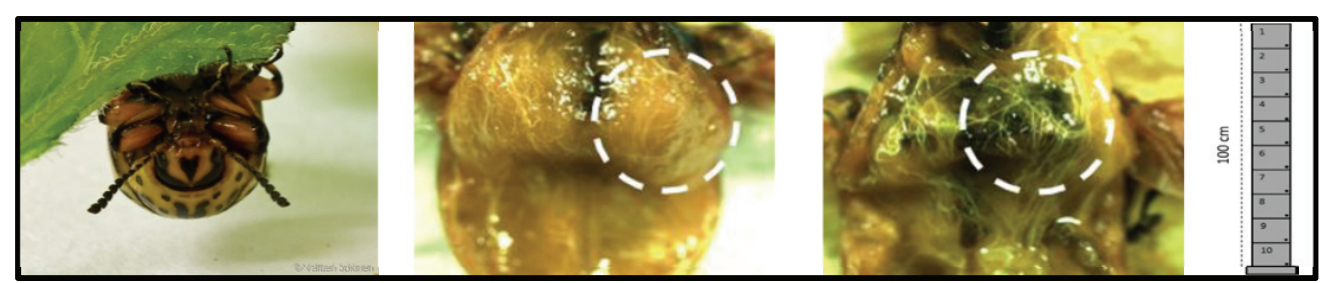

FIGURE 3 (a) Adult L. decemlineata females (15 days after eclosion), (b) fat body lobe (white circle) of pre-diapause and (c) reproductively active Italian female, (d) overwintering tube used in the burrowing depth experiment. 


\subsubsection{Comparison of two lipid extraction methods}

Since the most common solute used for lipid removal, 2:1 Chl:Meth (Folch et al. 1957), removes structural lipids, carbohydrates, glycerol and amino acids as well as neutral lipids (Newman et al. 1972), the size of lipid stores might be overestimated by this method (Williams et al. 2011). Therefore, I compared the differences in lipid amounts produced by extraction with either 2:1 Chl:Meth or diethylether in pre-diapausing adult $L$. decemlineata. The beetles used in this experiment were the fourth generation offspring of the beetles originating from Petroskoi (Table 1). Rearing conditions were the same as described in section 2.3.1, but the experiment was performed in 2009. A total of 34 males were mated with 38 females (1 male to 1-2 females) yielding 34 families. A total of 210 beetles were used and samples taken every second day from the day of emergence till 10 days later. Abdominal lipid content was gravimetrically estimated on the split abdomen. Apart from the solvent used, which was diethyl ether or 2:1 Chl:Meth, the method is the same as described in section 2.3.1. Lipid extraction method results between age groups were compared with a Spearman's' rank order correlation analysis and between groups paired samples comparisons were performed using the Wilcoxon rank order sum test. Nonparametric tests were employed due to heterogeneity of error variances. The lipid estimates of the split samples were tightly correlated (Spearman $r_{s}=$ $0.944, \mathrm{df}=210, \mathrm{p}=0.001)$. The methods produced different estimates on lipid content; Folch extraction consistently estimated significantly higher lipid content than DE extraction (Table 2). However, since the differences were fairly small (between 2.2 and $4.3 \%$ depending on age group), the Chl:Meth extraction is suitable for determining neutral lipid content in the abdomen of $L$. decemlineata. Importantly, no clear age dependent trend was apparent. Furthermore, unpublished data suggests that L. decemlineata does not produce large amounts of glycerol as part of diapause preparation, which could have become a problem at later ages than the 10 day point measured here (see Williams et al. 2011, Lehmann et al. unpublished).

TABLE 2 Wilxocon rank sum test of lipid content difference (\%) in beetle abdomen when analyzed with two extraction methods $(\Delta$ is the difference in lipid content between Folchs reagent and Diethyl:Ether).

\begin{tabular}{lllll}
\hline \hline Age & $\mathrm{N}$ & $\mathrm{Z}$ & $\mathrm{p}$ & \multicolumn{1}{l}{$\Delta$} \\
\hline 0 & 39 & -5.373 & $>0.001$ & 4.3 \\
2 & 16 & -3.051 & 0.002 & 3.6 \\
4 & 33 & -3.011 & 0.003 & 2.2 \\
6 & 54 & -4.611 & $>0.001$ & 3.8 \\
8 & 39 & -4.619 & $>0.001$ & 4.0 \\
10 & 29 & -4.573 & $>0.001$ & 4.0 \\
\hline \hline
\end{tabular}




\subsection{Fatty acid analyses (Study II)}

To study whether reproductive maturation or diapause preparation is associated with quantitative or qualitative changes in fatty acid profiles, I analyzed abdominal neutral and phospholipid fatty acids with Gas Chromatography - Mass Spectrometry (GC-MS). Fatty acids were analyzed from frozen abdomens which were freeze-dried, then thawed at room temperature and manually homogenized. Seven mg of homogenized tissue per sample was used $( \pm 0.01 \mathrm{mg}$, AM105DU; Mettler). The protocol is described in detail in study II. Briefly, membranes and tissues were broken down with $2 \mathrm{ml}$ Chl:Meth (2:1 [vol/vol]). Lipids were extracted by adding $1 \mathrm{ml}$ methanol, then 1 $\mathrm{ml}$ 2:1 Chl:Meth and lastly $0.8 \mathrm{ml} 0.9 \%$ sodium chloride $(\mathrm{NaCl})$. The mixture was sonicated, vortexed and centrifuged for $3 \mathrm{~min}$ at $3000 \mathrm{rpm}$ at $4{ }^{\circ} \mathrm{C}$. The lower phase (containing the lipids) was removed and the procedure repeated twice. The fractions were pooled and fractionated with SPE columns as described in section 2.3.2. The rough lipid content of individual samples was gravimetrically measured and samples diluted with chloroform as necessary to achieve a final lipid content of less than $1 \mathrm{mg}$. Samples were evaporated to dryness and fatty acids methylated with $1 \mathrm{ml}$ toluene and $2 \mathrm{ml}$ hydrogen sulfate methanol $(\mathrm{H} 2 \mathrm{SO} 4 \mathrm{MeOH})$ was added. After 15 hours at $50{ }^{\circ} \mathrm{C} 2 \mathrm{ml}$ Potassium Carbonate (KHCO3 $2 \%$ ) and then $5 \mathrm{ml}$ hexane ether was added. Samples were shaken and then centrifuged for $2 \mathrm{~min}$ at $1500 \mathrm{rpm}$ at $4{ }^{\circ} \mathrm{C}$. The upper layer was moved to a new vial and the process repeated with the original vial. The second upper layer was added to the first in the new vial and then evaporated to dryness. The tube was rinsed with $1 \mathrm{ml}$ of methanol and the solution moved to a screw-capped gas chromatography vial (Agilent 5182-0714) and evaporated to dryness. Vials were sealed with parafilm and stored at $-20^{\circ} \mathrm{C}$. Before analyzing, $500 \mu \mathrm{l}$ of hexane was added to each vial.

Fatty acid methyl esters (FAME) were analyzed by GC-MS using a HP 6890 GC equipped with Agilent DB-23 capillary column (30 m, 0.25 mm ID, 0.25 $\mu \mathrm{m}$ phase thickness) and a HP 5973 Mass Selective Detector, Global Medical Instrumentation Inc. Ramsey Minnesota). The modified timer program of Härtig et al. (2008) was used to separate fatty acids from each other. The different FAs were identified by retention time and by MS spectra. The position of the double bonds in the fatty acids were determined by Agilent GC/MSD ChemStation with fatty acid standard Supelco ${ }^{\circledR} 37$ component FAME mix 10 $\mathrm{mg} / \mathrm{ml}$ in methylene chloride (Sigma-Aldrich). The FAs were expressed as percent of the total identified fatty acid methyl esters. I calculated the molar proportions of the single fatty acids based on a $1 \%$ cut off limit. Fatty acids found under this percentage (when averaged within the data subsets) were designated trace fatty acids and were not included in the statistical analysis. The unsaturation ratio (U/S) was calculated by dividing the total proportion of unsaturated with saturated fatty acids. The UI, the average number of double 
bonds per fatty acid, was calculated as: $\Sigma$ (\% mono- $+2 \times \%$ di- $+3 \times \%$ triunsaturated fatty acids) / 100.

\subsection{Quantitative real-time PCR (Study III)}

Analysis of population dependent differences in ontogenic trajectories of gene expression in diapause development related genes was performed with quantitative real-time PCR (qPCR). First, total RNA was extracted from the head and thorax of individual beetles with Trizol-RNeasy RNA isolation of cultured cells (Genomics Laboratory, UMC Utrecht/MGK/Version 2.1, 18-72007) with slight modifications to suit whole tissue extraction. First, the head and thorax were placed on a paper towel to absorb the RNAlater solution before crushing and homogenizing tissues in $500 \mu \mathrm{l}$ Tri-reagent (Molecular Research Center, Inc. Cincinnati, OH, USA) with a plastic stick and left to incubate at room temperature $\left(20^{\circ} \mathrm{C}\right)$ for $5 \mathrm{~min}$. The extraction was followed by a clean-up step using RNeasy columns (RNeasy Mini Kit, Qiagen, Hilden, Germany) including DNase I treatment (RNase-Free DNase Set, Qiagen). The concentration and purity of RNA was measured with NanoDrop ND-1000 spectrophotometer (NanoDrop Technologies, Wilmington, DE, USA). RNA integrity was checked with Agilent Bioanalyzer (Agilent, Santa Clara, CA, USA). The RNA concentration of the samples was normalized to $100 \mathrm{ng} / \mu \mathrm{l}$ before generating complementary DNA using iScript ${ }^{\mathrm{TM}}{ }_{\mathrm{cDNA}}$ Synthesis Kit with oligo(dT) and random hexamer primers (BioRad Laboratories Inc. Hercules, CA, USA) following manufacturer's protocol and 100 ng of RNA as starting material.

The qPCR reaction mix with a total volume of $20 \mu \mathrm{l}$ contained $10 \mu \mathrm{l}$ of $2 \mathrm{x}$ SYBR Green Supermix (BioRad Laboratories Inc), $0.5 \mu \mathrm{M}$ of each gene-specific primer and $5 \mu \mathrm{l}$ of cDNA (diluted 1:8). The qPCR reactions were run on BioRad CFX96 instrument with cycling conditions as follows; initiation at $95{ }^{\circ} \mathrm{C}$ for 3 $\mathrm{min}$, followed by 39 cycles of $10 \mathrm{~s}$ at $95^{\circ} \mathrm{C}, 10 \mathrm{~s}$ at $56^{\circ} \mathrm{C}$ and $30 \mathrm{~s}$ at $72^{\circ} \mathrm{C}$. The qPCR was followed by melting curve analysis $\left(65-95^{\circ} \mathrm{C}\right)$ to check the purity of qPCR reaction. For each group (age/photoperiod/population) 4-7 biological replicates (individual samples) with 3 technical replicates were used. For interrun calibration, I used five control samples (different samples) in each run.

Primers used for qPCR were obtained from previously published studies (Yocum et al. 2011, Revuelta et al. 2011) for L. decemlineata. I also designed primers based on sequences of an annotated transcriptome of the L. decemlineata (Kumar et al. in review) and gene sequences available in GenBank for $L$. decemlineata and Chrysomela tremula using Primer3 (http://frodo.wi.mit.edu/primer3/, v. 0.4.0). Primers were checked for the 5' and $3^{\prime}$ stability values using NetPrimer (http://www.premierbiosoft.com/netprimer/). Primers were designed to have a $\mathrm{T}_{\mathrm{a}}$ as close to $56{ }^{\circ} \mathrm{C}$ as possible. In the case of JHE, two isoforms exist (Vermunt et al. 1997), and the designed primers may therefore amplify both 
isoforms. To investigate that the designed primers amplified the intended genes, sequencing reactions were performed using the BigDye ${ }^{\circledR}$ Terminator v3.1 Cycle Sequencing Kit (Applied Biosystems) and were run on an ABI 3100 automated sequencer and BLASTed against GenBank records (nucleotide database). Potential reference genes were selected based on available genetic data in GenBank for L. decemlineata and published reference genes used in gene expression studies of closely related species. The final set of reference genes, which were selected to the analyses, were based on most stable expression values across photoperiod (short and long day) and population (Petroskoi and Padua) groups within each age group (for 0 day-old beetles, across population only). Amplification efficiencies for all primer pairs of reference and target genes for each age group were calculated using 2-fold serial dilutions of pooled cDNA (6-8 dilution points) with three technical replicates. For all age groups, cDNA samples from both populations and photoperiods were pooled in calculation of amplification efficiencies.

\subsection{Hormone analogue topical applications (Study IV)}

An inherent part of diapause development in L. decemlineata is the decrease in JH titer (de Kort 1990). Since populations differ in respect to CPP (study I) and it has been suggested that life-history differences between individuals within a population or between populations could be mediated through hormones (see Zera 2007), my interest was to probe for potential population dependent differences in receptivity to manipulation of JH titers in adult beetles. JH titers were manipulated with topical applications of three substances. To increase JH titers I used the Juvenile Hormone analogue pyriproxyfen (Sigma-Aldrich). A dose of $1 \mu \mathrm{g}$ in $3 \mu \mathrm{l}$ of acetone was applied once, at the age of 1 day after adult eclosion (Koopmanshap et al. 1989). This dose was the smallest which successfully delayed or terminated diapause in L. decemlineata from a Dutch laboratory population reared in diapause inducing conditions in a previous study, and which incurred no mortality in treated beetles (Koopmanschap et al. $1989,1992)$. In contrast to increasing the JH titers, decreasing natural JH titers is more challenging and was in the present study attempted by using H17, an allatostatin mimic (kindly provided by Dr. Xingling Yang, China Agricultural University). I applied a dose of $0.3 \mathrm{nmol}$ of $\mathrm{H} 17$ diluted in $3 \mu \mathrm{l} 20 \%$ Dimethyl Sulfoxide (Sigma-Aldrich) and $80 \%$ acetone per application. Applications were repeated every third day because the effect of H17 decreases with time (Kai et al. 2009). As control I used $3 \mu \mathrm{l}$ of acetone, applied every third day. Applications were performed on the ventral thoracal plate and beetles were held in place with a small piece of plasticine. After applying the droplet, beetles were left for 30 second until they were returned to the jars. 


\subsection{Metabolic rate measurements (Study V)}

The resting metabolic rate (RMR) is a proxy of general metabolic activity and also linked to the utilization rate of stored energy (Randall et al. 2002, Kostal 2006). My interest was if beetles undergoing reproductive maturation and prediapause development have similar metabolic trajectories, and whether populations differ in RMR. The metabolic rate methodology in this thesis focuses on carbon dioxide production, which primarily stems from the citric acid cycle (Krebs \& Johnson 1937, Berg et al. 2002). As this measurement does not include oxygen consumption, I cannot therefore calculate respiratory quotients (Randall et al. 2002). $\mathrm{CO}_{2}$ production of individual 5 and 10 day old beetles was measured at the approximately same time during the synthetic photoperiod, between 2 and 4 hours after light on. This was to avoid any possible circadian rhythms in behavioral or physiological traits interfering with the metabolic rate (Matthews \& White 2011). After measuring metabolic rate, beetles were killed by freezing at $-80{ }^{\circ} \mathrm{C}$. No beetle was thus measured twice. From the 10 day old beetles, burrowing behavior was recorded first, and metabolic rate measured thereafter. To avoid $\mathrm{CO}_{2}$ emissions resulting from the assimilation of nutrients, beetles were starved for $24 \mathrm{~h}$ prior to $\mathrm{CO}_{2}$ measurements.

$\mathrm{CO}_{2}$ production was measured with a $\mathrm{Li}-6252 \mathrm{CO}_{2}$ analyzer (LiCor, Lincoln, NE, USA) connected to a flow through respirometry system. A weekly calibration of the $\mathrm{CO}_{2}$ analyzer with $470 \mathrm{ppm} \mathrm{CO}_{2}$ in nitrogen was used. Ambient air from which water vapor and $\mathrm{CO}_{2}$ were removed (with Drierite, WA Hammond Drierite, USA and Ascarite II, Acros Organics, USA, respectively) was pumped through the system (SS-2 pump; Sable Systems, Henderson, NV, USA). The flow rate was set to $150 \mathrm{ml} \mathrm{min-1}$ with a mass flow controller (840 Series; Sierra Instruments Inc, California, USA). Eight cylindrical glass respirometry chambers (volume $1.7 \mathrm{ml}$ ) (of which one empty chamber served as the baseline) were connected to a multiplexer (Sable Systems). The chambers were located inside a Peltier effect constant temperature cabinet (PTC-1; Sable Systems) in which the temperature was set to $23{ }^{\circ} \mathrm{C}$ and controlled with a temperature controller (Pelt-5; Sable Systems). Preliminary tests were performed to ensure that the incurrent air temperature that flowed through the respirometry chamber was stabilized with the ambient temperature in the cabinet. The multiplexer was programmed so that the series of seven beetle chambers was measured twice. The recording of each beetle lasted $5 \mathrm{~min}$ during which the moving activity of the beetle was recorded with an infra-red light scattering based activity detector (AD-1; Sable Systems). The sampling interval was $1 \mathrm{~s}$. Beetles were weighed $( \pm 0.1 \mathrm{mg}$, AM100; Mettler) after the measurement. Respirometry data was baseline corrected and converted to $\mathrm{ml}$ $\mathrm{CO}_{2}$ g- 1 h-1 by the acquisition and analysis software Expedata version 1.1.15 (Sable Systems). The metabolic value was the mean value of the respirometry recordings of two 5 min periods. From the activity data an absolute difference 
sum and a linear regression was calculated. The steepness of the slope (arbitrary number) describes the level of activity.

\subsection{Statistical analysis of the data}

\subsubsection{Analyses of quantitative traits}

Quantitative traits, such as lipid content, were analysed with factorial variance analysis models (analysis of variance, ANOVA) (studies I, II, IV and V), since I was interested in interactions, too (population, age, sex, photoperiod). Mass was used as covariate in some analyses (then analysis of covariance, ANCOVA). This is because mass has a strong influence on several of the traits, such as fecundity or lipid content. Normality of the response trait and covariates were analysed with Kolmogorov-Smirnov and Shapiro-Wilk tests and homogeneity of variance with Levene's test. If the data was not normally distributed, transformations of the data were employed. In case of violations of parametric assumptions which could not be corrected with transformations, non-parametric statistical tests were used. In these cases I generally used a factorial generalized linear regression model (GZLM) for analyses. In cases were assumptions were only marginally violated, both a parametric and nonparametric test was employed, which in all cases yielded the same results. Fecundity (study I and IV) was zero-inflated due to females preparing for diapause and therefore analysed with a Poisson GZLM. Binary response data (e.g. burrowed or not) was analysed with binary logistic regression models (BLR) or a binary logistic GZLM. Generally, non-significant interactions were removed from the final models (Sokal \& Rohlf, 2003). In some cases, also sex was removed since it did not have any significant influence on the measured trait nor improved the amount of variation explained (tracked via the Akaike information criterion, or $\mathrm{R}^{2}$ value). In case of significant interactions, main effects were post-hoc analyzed univariate tests with Bonferroni corrections for multiple comparisons. Analyses were performed with the IBM SPSS Statistics 17.0, IBM PASW Statistics 18.0 and IBM SPSS Statistics 20.0 (IBM SPSS Inc., Chicago, IL, USA) statistical software packages.

\subsubsection{Analysis of fatty acid profiles (Study II)}

The photoperiod and population dependent differences in fatty acid proportions within the 4 age groups were analysed with a Kruskall-Wallis test. A non-parametric test was employed due to heterogeneity of error variances. Significant differences were post-hoc analysed with a Kruskall-Wallis univariate test with Bonferroni adjustments for multiple comparisons. The age dependent shift in the pooled data (photoperiod and population) was analysed with a Kruskall-Wallis test as described above. The four ages were divided into two groups: pre-diapause to diapause initiation phase (0-10 days) and diapause 
initiation to maintenance phase (10- 170 days). A principle component analysis (PCA) on the molar percentages of the fatty acids was performed to visually present the age dependent changes.

\subsubsection{Analysis of gene expression (Study III)}

Relative expression values were calculated using the normalized expression method $(\Delta \Delta(\mathrm{Cq}))$ with CFX Manager software (v.2.1, BioRad Laboratories Inc). Statistical significance of pairwise differences in expression values between photoperiods within population and between populations within photoperiod in each age group were performed with REST 2009 software (with 10000 iterations) (http://www.gene-quantification.de/rest-2009.html). This program calculates statistical significance of expression ratios using bootstrapping and randomization methods which take into account the amplification efficiencies of the target and reference genes.

\subsubsection{Analysis of resting metabolic rate (Study V)}

To investigate the association between age, population and rearing photoperiod on RMR, the mass-specific RMR $\left(\mathrm{ml} \mathrm{CO}_{2} \mathrm{~g}^{-1} \mathrm{~h}^{-1}\right)$ was square root transformed to improve normality and then analysed with a factorial general linear model (GLM). Age, sex, population and photoperiod were entered as fixed factors and activity during the RMR measurement as a covariate. To study the association between the burrowing behavior and RMR, only 10-day old beetles were used and burrowing behavior (burrowed/surface) was included as a fixed factor in addition to photoperiod, population and sex. Activity was added as a covariate. The results were consistent when above models were built using absolute RMR $\left(\mathrm{ml} \mathrm{CO}_{2} \mathrm{~h}^{-1}\right)$ as a dependent factor and body mass at the time of measurement as covariate. 


\section{RESULTS AND DISCUSSION}

\subsection{Patterns in growth related traits, critical photoperiod and diapause incidence suggest adaptation to local season length}

The studied traits which related to development and growth showed variable clinal patterns. I found that the northern population (Petroskoi) had a significantly shorter development time than the two southern populations (Emmen and Padua) and that there was no difference in development time between the southern populations. The difference between the northern and southern populations was only one day, which might seem fairly ecologically insignificant. It is important to note that the beetles were maintained at optimal growing conditions during the experiment $\left(23^{\circ} \mathrm{C}\right)$ (Alyokhin 2009) and a larger difference between northern and southern populations might have been observed at lower ambient temperatures (see Boman et al. 2008, Lyytinen et al. 2009). Beetles from the northern population had lighter body weight at emergence in both experiments (I and II). However, they had the highest adult weight gain, and consequently the difference in eclosion weight between the northern and southern population disappeared by the age of 6-10 days and in Study II the northern population even exceeded the southern population in weight at the age of 10 day. The differential adult weight gain could be explained by the beetles from Petroskoi needing to accumulate more energy reserves than in southern Europe due to longer winters to ensure survival (Denlinger \& Lee 2010). Since adults from the Petroskoi gain weight faster and carry higher amounts of lipid (Study II), which correlate strongly with overwintering survival (Piiroinen et al. 2011), than the adults from Padua, the growth patterns suggest compensatory growth (Blanckenhorn \& Demont 2004). In other words, the size of the ecologically relevant stage facing the hardest selection (the adult initiating diapause) appears to remain constant with increasing latitude. The populations from Emmen and Petroskoi did not differ in early adult weight gain. This is possibly explained by qualitative, rather than quantitative, differences between the populations, such as lipid store 
composition (Arrese \& Soulages 2010, Study II) or utilization during diapause (Hahn \& Denlinger 2011, Lehmann et al. unpublished).

The growth pattern results might be partially confounded by differences in voltinism between the populations. The northern population (Petroskoi) is most likely univoltine, while middle European populations have been reported to be bivoltine (de Wilde et al. 1959). Since development time can change depending on generation in multivoltine species (see Abrams et al. 1996), it is possible that the shortest photoperiods used in Study I and the 12 hour photoperiod in Study V might be interpreted as spring, rather than autumn, in the populations from Emmen and Belchow. This could explain why their development time was as long as in the Paduan population (see Gotthard et al. 1999).

I show that CPP for diapause follows a robust latitudinal pattern (Figure 4). The estimated CPP of the populations correspond to photoperiods in the mid of September, beginning of August and in the mid of July, at the respective latitudes. These CPP estimates reflect the end of benign season length for the Colorado potato beetle (see Figure 1d) at the given latitudes and suggest that invasion to northern latitudes has been accompanied by evolutionary changes in critical photoperiod (e.g. Gaston, 2003). The results correspond to the so called Danilevski's rule that the CPP becomes about $1 \mathrm{~h} 30$ min longer per $5^{\circ}$ of increased latitude (Danilevski 1965, Danilevski et al. 1970). Divergence can be estimated in darwin units based on the range of annual expansion speeds (80 $130 \mathrm{~km} \mathrm{year}^{-1}$ ) and the distance between the populations (Haldane 1949, Johnson 1967). Evolution in CPP has been rapid as indicated by darwin unit estimates (between Emmen and Padua, 12537 - 20198 units). The divergence has, however, slowed down towards the north (between Emmen and Petroskoi, 7021 to 11234 units).

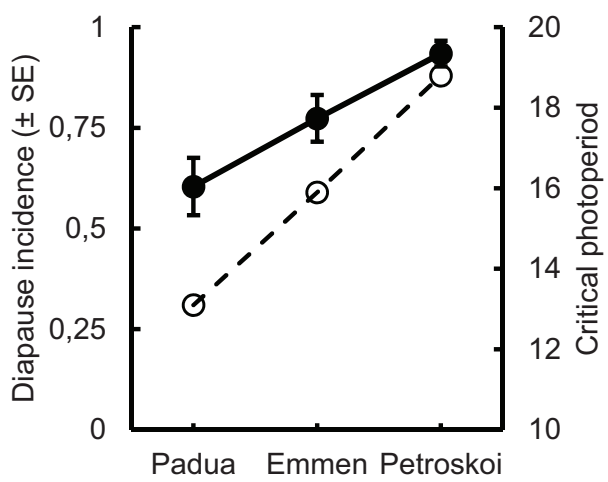

FIGURE 4 Diapause incidences $( \pm$ SE) (filled circles) and critical photoperiod (open circles) of three L. decemlineata populations (Padua $45^{\circ} \mathrm{N}$, Emmen $52^{\circ} \mathrm{N}$ and Petroskoi $62^{\circ} \mathrm{N}$ ). The incidences were calculated based on the proportion of beetles which burrowed when reared under the shortest two photoperiods ( 9 and 12 hours) (study I). 
Also diapause incidence differed between the populations (Figure 4). It increased with latitude from $60 \%$ in Padua to close to $100 \%$ in Petroskoi. As these populations have established permanent populations quite recently, also this result suggests rapid adaptive divergence between the populations. The most likely selection factor has been autumn and winter conditions. If $L$. decemlineata individuals are not prepared for overwintering (remaining on soil surface, or without large lipid stores), their overwintering mortality can be close to $100 \%$ in northern conditions (Piiroinen et al. 2011, Study II). Instead beetles in a un-diapausing state may survive winter at low latitudes where the winter is temperate and thus milder. Rather interestingly, in most older studies on the population from Emmen, diapause incidence was found to be close to $100 \%$ when reared in short photoperiods at a range of temperatures (see de Wilde et al. 1959 for references). Since diapause incidence was estimated to be around 77 $\%$ in this population in the present data, a substantial decrease in diapause incidence is apparent. This reduction in diapause incidence could be due to climate shifting, since average annual temperature has increased by $1^{\circ} \mathrm{C}$ during the last 100 years in the Netherlands (Bresser et al. 2005), which has led to shorter and milder winters. This relaxation in selection pressure based on winter mortality has possibly led to the inclusion of some non-adapted beetles to the population, if they survive winter even though they are not in diapause.

There was a positive correlation between resurfacing frequency after burrowing and rearing photoperiod in all populations. Since resurfacing behavior is associated with stress and overwintering mortality (data not shown, but see Piiroinen et al. 2011), the results indicate that the long photoperiods were perceived as stressful for the beetles. The photoperiods over $18 \mathrm{~h}$ were longer than is experienced in nature for the lower latitude populations. These long photoperiods could induce stress due interference with the normal counter mechanism, which depends on temporal patterns of protein expression and degradation and could require a minimum "dark" period to complete a molecular feedback cycle (see Saunders 2002, Kostal 2011, Kauranen et al. 2013). The results could suggest that adaptation to use a longer photoperiod as cue for diapause might be more difficult than adaptation to use shorter critical photoperiods. This conclusion is also indicated by a faster divergence in CPP between Emmen and Padua, than Emmen and Petroskoi.

It is however important to note that conditions in the field are more variable than laboratory conditions. For instance, the photoperiod in northern Europe the photophase can shorten by over 1 hour per week during late summer, temperature decreases non-linearly across latitude during late summer, and lastly, food quality changes with the progression of the growth season. Our experimental set-up, although designed to pinpoint the effect of photoperiod on pre-diapause development, could be offsetting cues which are of large importance in the field. Significantly higher diapause incidence is often achieved when rearing animals in conditions of both short photoperiod and low temperature (de Wilde 1959, Tauber et al. 1986, Salminen 2011). This could especially be a problem in the very long photoperiods, where beetles could be depending on other cues than photoperiod alone to make decisions. It is 
however more likely that differences between the populations would be larger if reared under field conditions, due to larger temperature fluctuations in the north and a faster late summer decrease in temperature. Indeed, in the cold adapted malt fly Drosophila montana, photoperiodic response curves have steeper slopes when reared at low ambient temperature than high ambient temperature (Salminen 2011). It should therefore be highlighted that the regulation of diapause induction often is under the control of several environmental factors which can affect different aspects of the formation of the final diapausing phenotype independently, or in concert (Tauber et al. 1986, Danks 1987, Bradshaw \& Holzapfel 2007, Nelson et al. 2010).

\subsection{Diapause preparation is associated with neutral lipid sequestering, but not with homeoviscous adaptation or metabolic suppression}

\subsubsection{Energy store sequestering: total lipids}

Both the northern and southern population reacted to the short day photoperiod by increasing abdominal total lipid content and decreasing water content. This suggests that in the short photoperiod, the beetles prepared for diapause. The conclusion was also supported by their low mortality during diapause. In the long day photoperiod, large inter-population differences were found. The southern population ceased lipid accumulation after 5 days, while the northern population continued lipid accumulation as beetles in the short day photoperiod. This indicates that the southern population used energy gained from food for other purposes, such as reproductive maturation. Abdominal total lipid stores in 10 day old beetles were shown to be predominantly composed of neutral lipids (85 \%), most likely representing storage triacylglycerols. This estimate was gained through Chl:Meth extractions, and is in reality probably around $5 \%$ points lower (Table 2).

Lipid stores of beetles preparing for diapause were very large and constituted around $50 \%$ of dry mass. There are some studies showing that energy store size decreases quite modestly during the overwintering period in L. decemlineata (Uschatinskaya 1956, Piiroinen unpublished). This raises the question of what the function of so large energy stores is. One explanation lies in post-diapause energetic demands (Hahn \& Denlinger 2007) where stored energy acts as important starting capital for among other the re-building of flight muscles, growth of reproductive organs or dispersal (Stegwee et al. 1963, de Kort et al. 1969). L. decemlineata, whose ovaries and flight muscle tissue is degenerated prior to diapause, and rapidly rebuilt after diapause is terminated (Stegwee et al. 1963) also needs energy for spring dispersal (Voss \& Ferro 1990). Therefore it is reasonable to assume that post-diapause energetic demands could be the main cause for intensive pre-diapause lipid sequestering. 
Especially if there is little potato available when diapause is terminated. Another fact which suggests that lipids are used for post-diapause demands rather than during diapause itself, is the energetically and physiologically demanding up to 9 years lasting prolonged diapause in L. decemlineata (Tauber \& Tauber 2002). If energy stores would be severely depleted after one overwintering season, then a prolonged dormancy of 9 consecutive seasons (without intermittent feeding), should be energetically very challenging (see Hanski 1988). The mechanism by which stored energy is utilized during diapause might therefore be of larger relative importance for overwinter survival (Hahn \& Denlinger 2011).

Both the absolute and relative lipid content was higher in females than in males both as part of pre-diapause development and during reproductive maturation. This is probably due to the high energy requirements of vitellogenesis in females (Klowden 2007, Hahn \& Denlinger 2007, Arrese \& Soulages 2010). Although male courtship might incur some costs in L. decemlineata, such as spermatogenesis, mate finding and mate guarding (Szentesi 1985, Alyokhin \& Ferro 1999, Arnqvist \& Rowe 2005), no large difference in relative or absolute lipid content was found between males preparing for diapause and males undergoing reproductive maturation (Study II). Instead populations differed in both relative and absolute lipid content, males from the northern population gathered more lipid than males from the southern population. This could reflect a need for males from northern population to prepare for a longer winter, or conversely, a shorter summer with increased time constraints for reproduction. Also in Study I a large difference in behavior was found between the sexes. Male beetles mated with females in almost all photoperiods and overwinter survival in these males was much higher than in females which had oviposited (data not shown). This again suggests that reproduction might carry a relatively smaller cost for males than females, and that sexes might have been under different energy metabolism related selection pressures during the pre-diapause period.

\subsubsection{Homeoviscous adaptation: Fatty acid profiles}

Fatty acid profiles of both the neutral lipids and the phospholipids showed large shifts during the first 10 day of adult life, predominantly in the fractions

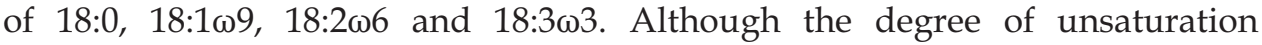
increased with age, it was not higher in diapausing than non-diapausing beetles. This indicates that $L$. decemlineata does not increase diapause related cold tolerance via homeoviscous adaptation, and might have developed other means to cope with suboptimal temperatures, such as behavioral adaptations (Milner et al. 1992). It is furthermore possible that cold tolerance is induced at a later stage than during the pre-diapause period (Lehmann unpublished). In some species, such as Pyrrchocoris apterus, short photoperiod primes cold tolerance, with actual low temperatures then leading to the final cold tolerant state (Hodkova et al. 2002, Hodkova \& Hodek 2004). The temperature used in this experiment during diapause $\left(5^{\circ} \mathrm{C}\right)$ has been shown to induce an increase in 
cold tolerance in several other temperate ectotherm species (e.g. Kostal \& Simek 1998, Holmstrup et al. 2007, van Dooremalen \& Ellers 2009, Kostal 2010). However, there was no significant difference in unsaturation ratio (US) or unsaturation index (UI) between the 10 day old beetles and individuals which had spent 170 days in diapause (diapause maintenance), which strongly suggests that homeoviscous adaptation is not part of the diapause program in this species. In addition, since the 10 day beetles in both populations and photoperiods attained respectably high US values, lipid stores and membranes might inherently attain large enough lipid fluidity to allow for successful overwintering (see Lee et al. 1995, also see results section 3.5).

\subsubsection{Metabolic rate}

The beetles from Padua and Petroskoi had different resting metabolic rate (RMR) trajectories during the first 10 days of adult life. At 5 days after emergence, beetles originating from Petroskoi had higher and at day 10 lower RMR than beetles from Padua in both photoperiods. Furthermore, the RMR was higher under the short day (SD) than under the long day (LD) photoperiod in both populations at 5 days after emergence. By day 10, the difference in RMR between photoperiods had disappeared. The differences in the trajectories between the populations can be explained in two ways. Absolute metabolic rates could differ, northern beetles being more efficient at foraging and dispersing during early life, and strongly suppressing metabolic rate (and energy loss) as fast as lipid sequestering is finished (Study II). However since the RMR was higher at 5 days than at 10 days after emergence in both populations, the decrease is probably an inherent part of the developmental process (Hack 1997, Roberts \& Rosenberg 2006, Grodzicki \& Walentynowicz 2011). Therefore the results might reflect differences in rates, rather than absolute metabolic activity levels and the southern population could also show suppression of RMR when a few days older (Lehmann et al. unpublished). The study design unfortunately does not allow us to separate these alternatives.

The results show population dependent adjustment of RMR during early adult life, indicating adaptation to a short growth season in northern Europe. The result also highlights an important caveat in studies on metabolic rate where comparative often large scale patterns are assessed (Chown \& Gaston 1999). Namely that age can have a significant non-linear impact on RMR in addition to the often linear decrease in RMR which usually accompanies senescence (Grotewiel et al. 2005).

\subsection{Ontogenic patterns in expression of diapause related genes support that adaptation to northern conditions has occurred}

The genetic and molecular mechanisms underpinning diapause development are much less well known than the behavioral and physiological changes. I 
therefore took a candidate gene approach to study inter-population differences in the expression patterns in genes associated with diapause development. The genes were associated with regulatory, stress tolerance related or metabolic functions. In general, gene expression differences between the beetles from Petroskoi and Padua increased with age in both photoperiods, especially in the stress tolerance related genes diapause protein 1 (DP1) and diapause associated transcript 2 (DAT2). These genes were strongly up-regulated in individuals preparing for diapause. Smaller differences were seen in other genes, such as heat shock protein 70B (HSP70B), beta-glucosidase (BGlu) and the insulin like receptor $(I n R)$. The conclusion made in previous studies (Piiroinen et al. 2011, Lindström unpublished, studies I, II, V) that beetles from different latitudes time their diapause preparation to match local photoperiod indicating local adaptation is my thesis supported at the gene expression level. Differences in expression ontogenies (within and between populations at the age of 5 and 10 days of age) suggest that diapause preparation in the northern population is faster, which is advantageous. Alternatively, absolute expression levels of energy storage (DP1) and stress related proteins (DAT2) might be higher in the beetles from Petroskoi which would be beneficial for survival in northern Europe where the overwintering period is much longer, minimum temperatures are lower, and temperature fluctuations are larger than in southern Europe (Bradshaw \& Holzapfel 2010).

My experiment does not suggest a clear role of $\operatorname{In} R$ or the forkhead transcription factor (foxo) in the pre-diapause regulatory program as reported for diptera (Sim \& Denlinger 2008). This could be due to structural differences in the regulatory pathway in coleoptera compared to diptera. It is also possible that the temporal resolution of our study was too low (samples every 5 days) or that the last samples were taken at a too early point of the diapause program (especially in the Paduan beetles) to reveal the potential roles. A methodological explanation for the absence of a clear role of foxo is that only the head and frontal thorax of the beetle was used for the expression analysis. This part does not encompass all parts of the fat body (de Loof \& Lagasse 1970), where foxo expression has been found to be high (Sim \& Denlinger 2013). Thus it is possible that my results do not represent the full scale of foxo expression. Unlike foxo, InR expression is more widely distributed and high in the brains of for instance Spodoptera littoralis (Iga \& Smagghe 2011). However, since DP1 expression, which is exclusively expressed in the fat body of L. decemlineata (de Kort 1996) showed clear differences, I am confident that also other genes expressed in the frontal fat body should show relevant responses.

One goal with this study was to assess whether a population and photoperiod dependent difference in the expression of circadian clock genes could be seen. It has been suggested that the circadian clock is causally involved in mediating latitudinal differences in CPP (see Kostal 2011). Direct evidence is however lacking and there are several studies showing de-coupled responses between circadian gene expression and CPP (see Bradshaw \& Holzapfel 2010). In the study a strong association between the expression of any circadian gene and diapause development or reproductive maturation between the 
populations was not seen. A slight up-regulation of the gene timeless (tim), was of similar nature as in a previous study on Wyeomyia smithii individuals preparing for diapause (Mathias et al. 2005). Therefore my results support studies which suggest that the circadian clock is not necessarily causally involved in mediating seasonal rhythms (Bradshaw et al. 2001, 2006).

Finally, I studied the association between the expression of a hypothetical desiccation protein gene DAT2 and water content. Since body water content is often actively decreased to increase body fluid osmolarity and to decrease freezing point (Salt 1961, Danks 2000), desiccation proteins are needed to buffer cellular functions during the formation of the diapausing phenotype (see Yocum 2003). A strong negative correlation was indeed seen, which lends further support to the idea that DAT2 could have an important role in buffering against desiccation stress in L. decemlineata during diapause.

\subsection{Life-history adaptation has probably not proceeded through change in the endocrinological machinery}

Two inherent parts of pre-diapause development in L. decemlineata are the retardation of ovarian maturation and burrowing into the soil (de Loof \& Lagasse 1970, de Kort 1990). Pre-diapause development is accompanied by decreased Juvenile Hormone III (JH) titers, which has been suggested to be an important effector of diapause (de Kort 1990, Gilbert 2012). I therefore investigated population dependent differences in the receptivity to manipulation of $\mathrm{JH}$ titers. Differences in receptivity could indicate that population divergence in response to photoperiod is driven by changes in the endocrinological machinery inherently driving life-history switches (Zera 2007, Flatt and Heyland 2011, Oostra 2013). Manipulation of the JH titer with pyriproxyfen (a juvenile hormone analogue, JHA) led to increased egg production and decreased burrowing propensity but there was no difference among populations (except for Polish beetles reared under SD conditions). Manipulation of $\mathrm{JH}$ titer with $\mathrm{H} 17$, a substance that decreases $\mathrm{JH}$ titers in cockroaches (Kai et al. 2009), did not affect burrowing propensity. Manipulation with $\mathrm{H} 17$ was nevertheless successful, since I could manipulate oviposition rate, which decreased in the Russian and Polish populations after H17 application. While the effect of the JHA has been assessed in L. decemlineata previously (e.g. Koopmanshap et al. 1989) it would be important to follow up the effectiveness of the H17 in more detail. However, since burrowing propensity could only be manipulated with the JHA (a strong dose) (Koopmanshap et al. 1994), it suggests that burrowing is more strongly under photoperiodic control than oviposition, and possibly that the link between photoperiod, JH titer and burrowing is not linear.

I did not see any significant population dependent differences in burrowing in response to the topical application treatments, even though the 
populations strongly differed in respect to photoperiodic response (as in Study I). I therefore conclude that even though a slight population dependent difference was found in $\mathrm{H} 17$ receptivity concerning egg production, the overall small differences between the populations indicate that latitudinal variation seen in life-history and physiological traits (Danilevski 1965, de Kort 1990, Boman et al. 2008, Study I, II, III, V) are probably not driven by local adaptation in the mechanisms directly related to $\mathrm{JH}$ reception. Before drawing final conclusions it would however be important to assess $\mathrm{JH}$ titers directly (Zera 2007) to see whether populations differ in baseline $\mathrm{JH}$ values (which could explain why they differ in receptivity as well).

\subsection{Varying degrees of behavioral plasticity in burrowing could indicate erosion of plasticity due to harsher winters}

Successful invasion to a novel environment might require that the invading species is able to match its life-history with novel biotic and abiotic requirements in the invaded environment (Elton 1958, Sax et al. 2005) or alternatively, is capable of avoiding adverse conditions through behavior (Sakai et al. 2001, Duckworth 2009, Wright et al. 2010, Phillips \& Suarez 2012). Lipid content and RMR, two important physiological traits involved in pre-diapause development (Hahn \& Denlinger 2007), were analyzed in connection to burrowing behavior from individual beetles. I found significant population dependent differences in how strongly burrowing behavior was associated with neutral lipid content in 10 day old beetles. The association was strongly related to photoperiod. In the SD photoperiod beetles from both populations (Petroskoi and Padua) which had burrowed into the soil had on average $7.7 \mathrm{mg}$ more lipids than those still on the soil surface. In the LD photoperiod, however, the populations differed in total lipid content depending on whether beetles were on the surface or were burrowed into the soil. While Padua and Petroskoi beetles on the surface had similar amounts of lipids $(11.9 \pm 1.6$ and $11.6 \pm 1.3 \mathrm{mg}$ respectively), the burrowed beetles from Petroskoi had significantly higher lipid content than those from Padua $(20.1 \pm 1.6$ and $13.1 \pm 2.1 \mathrm{mg})$. Contrary to lipid content, RMR only differed between the populations and depended on behavior but not photoperiod. Beetles on the soil surface had a higher RMR than beetles that were burrowed into the soil. Additionally, the beetles from Padua had higher RMR than those from Petroskoi regardless of whether or not they were burrowed. The majority of the inter-population variation in RMR in 10-day old beetles is due to differences in the RMR of beetles that were on the surface.

In conclusion I found that diapause behavior was weakly associated with two important underlying physiological traits (resting metabolic rate and storage lipid content) in the southern population compared to the northern population. The difference between the populations might be due to gradual 
erosion of behavioral plasticity during the latitudinal range expansion northwards. Progressively harsher seasonal abiotic conditions may have required a stronger association between burrowing behavior and lipid content, which suggests that plasticity in the behavior on its own has not been sufficient for successful range expansion, unlike in several other ectotherm animals (Gabel et al. 2011, Hanshew \& Garcia 2012, Harms \& Turingan 2012). However, it remains feasible that behavioral plasticity in burrowing behavior has facilitated range expansion in more benign environments since the Paduan population seemed to retain the ability to burrow even though physiologically unprepared (see Wright et al. 2010).

Apart from the timing (Study I) and physiology (studies II, III, IV, V) associated with burrowing, also the location and depth of the overwintering burrow itself has been shown to carry energetic and survival benefits in several species (Leather et al. 1993). Overwintering under snow assists in thermal buffering, but the buffering effect subsides with increasing age and compactness (wetness) of the snow, which often is the case during the overwintering period (Niemann 1957). Therefore burrowing into the soil can be beneficial, especially in areas where snow cover can vary substantially between years (such as the northern temperate zone) (Leather et al. 1993, Williams et al. 2000). However, burrowing deep into the soil can be physically challenging, and for instance in spiders there are virtually no known examples of burrows at depths exceeding $10 \mathrm{~cm}$ (Kirchner 1987). L. decemlineata is sturdy enough to burrow exceedingly well, in spite of its slender (leptino) legs (tarsa). Indeed, burrows at depths of $60-80 \mathrm{~cm}$ have been recorded (Kuusik et al. 2001). In our experiment, no difference in burrowing depth was detected between the populations $\left(\mathrm{F}_{1,76}=0.365, \mathrm{P}=0.548\right)$ (Figure 5). The result suggests that there has not been selection for increased depth during the northwards expansion. Beetles might not been exposed to the selection because they are able to shift overwintering burrow depth and location during winter (Milner et al. 1992). Thereby beetles can actively choose location of the overwintering hibernaculum in order to avoid stress (Costanzo et al. 1998) and potentially also optimize energy expenditure (see Hahn and Denlinger 2011). This plasticity might shield beetles from selection by low winter temperatures for even deeper burrows, or otherwise enhanced cold tolerance. Furthermore, it might be that in $L$. decemlineata soil characteristics, such as soil type, water load, grain size, and oxygen availability, not depth per se, might be the major factors in determining overwintering survival (e.g. Costanzo et al. 1997, 1998, Hiesaar et al. 2006). However, it is possible population dependent differences in burrowing depth might become clear only at more challenging thermal conditions, which better reflect local overwintering environments.

The males from both populations burrowed on average $4.9 \mathrm{~cm}$ deeper than their female counterparts $\left(\mathrm{F}_{1,75}=4.704, \mathrm{P}=0.033\right)$. This could be related to differences in cold tolerance driven by sexual dimorphism in body size. Compared to females, males are smaller in size which means they have higher water content and consequently higher freezing susceptibility (Costanzo et al. 1998, Lee 2010). Therefore they need to burrow deeper in to the soil than 
females in order to avoid low, harmful temperatures. From the perspective of both sexes, overwintering by burrowing into the soil has probably been of major importance in facilitating range expansion (Hsiao 1985).

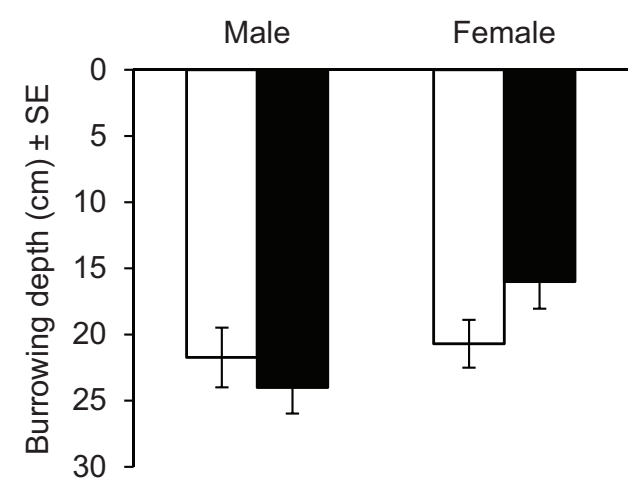

FIGURE 5 Burrowing depths ( $\mathrm{cm} \pm \mathrm{SEM}$ ) of adult female and male L. decemlineata from Padua (open columns) and Petroskoi (filled columns) and reared under a diapause inducing short photoperiod.

A major objective of my thesis was to analyze pre-diapause development from several partly overlapping levels of biological organization; from gene expression through physiology to behavior. In older studies on diapause development in L. decemlineata, and many other species, behavioral cues, such as burrowing, were used as sole measure of diapause initiation (e.g. de Wilde et al. 1955, Goryshin et al. 1987, Tauber et al. 1988, Senyanake et al. 2000). However, it is shown in many studies, including my thesis, that behavior can be highly variable and not necessarily causally linked to an underlying physiological status (such as the size of energy reserves). Knowing a beetle has entered diapause based on behavior would require tracking overwintering survival, which is seldom done (or reported) in older studies. In study V of my thesis, I show that Paduan beetles which are unprepared for diapause, in terms of lipid content, can and will burrow for diapause. Consequently they suffer high overwintering mortality (study II, Lindström et al. unpublished). Beetles might burrow into the soil because they do not find a mate (beetles were reared individually), not because they are entering diapause. It is however quite possible that the Italian beetles could survive a shorter and warmer overwintering period than in my experiments, which better corresponds to conditions in their native range in northern Italy. Since the northern population has a strong association between behavior and physiology (burrowed individuals have large lipid stores), and the southern one has a weak association, the results indicate that diapause initiation related behavior can vary between individuals in a population dependent manner. These results suggest that studies which use behavioral cues to indicate physiological status without validating the association on the level of the individual, might be oversimplifying a possibly complex and variable relationship. 


\section{CONCLUSIONS AND FUTURE DIRECTIONS}

Adaptation to high latitudes requires that species can respond to the shortening of the growth season as well as to the lengthening of winter. The results of this thesis, when put together, suggests that the invasive European L. decemlineata beetles show adaptive variation in life-history and stress tolerance related traits which has allowed populations to synchronize with the seasonality of the local environment. This was seen as faster adult weight gain as well as faster and larger lipid accumulation in the northernmost population when compared to southern populations (studies I, II). The adult growth patterns therefore suggest compensatory growth (Blanckenhorn \& Demont 2004) in response to temporal constraints imposed by a short growth season. The initiation of diapause under longer photoperiods (population dependent variation in $\mathrm{CPP}$ ) together with the high lipid accumulation of the northernmost population also suggests adaptation to the season length at high latitude (studies I, II). This adaptation has been rapid as estimates of divergence in the critical photoperiod among populations were high and the species has expanded its range from sub-tropical to almost sub-arctic latitudes in a time span which in ecological and certainly in evolutionary terms could be called short. Thus my results lend support to the hypothesis that photoperiodic synchronization is a major eco-evolutionary factor in determining range expansion success (Bradshaw \& Holzapfel 2007, Saikkonen et al. 2012, see other invasive species in: Dalin et al. 2010, Sadakiyo \& Ishihara 2012, Urbanski et al. 2012). My results furthermore support conclusions made previously that the L. decemlineata adult in diapause seems to be the ecophysiological stage facing the hardest selection at high latitude (Valosaari et al. 2008).

I also studied three relatively well known potential mechanisms which could be driving the divergence between the populations in diapause initiation (studies I, III, IV). These mechanisms include the photoperiod measuring molecular clock (the circadian clock), as well as an important molecular signaling route communicating between the molecular clock and effector areas (the insulin signaling pathway) and the main effector hormone regulating the decision to enter diapause (juvenile hormone III) (Bradshaw \& Holzapfel 2007, 
Gilbert 2012). The circadian genes did not show strong diapause development related patterns, nor, unsurprisingly population dependent differences (study III). This suggests that the circadian clock might not be involved in photoperiodic adaptation in $L$. decemlineata. The finding supports the hypothesis by Bradshaw and Holzapfel of a separate, non-circadian, mechanism driving the evolution of the seasonal timer in Wyeomyia smithii (Bradshaw et al. 2001, 2006). Also the expression of $I n R$ and foxo supports this hypothesis, since no major differences were found between beetles preparing for diapause and undergoing reproductive maturation, within or between the populations (study III). It seems likely that the endocrinological machinery responding to photoperiod is similar in the studied populations because I found only slight differences in JH receptivity between the populations (IV). One reason for the why rapid life-history evolution might not proceed through the endocrinological machinery could be that while hormones have large pleiotropic effects which might facilitate life-history evolution, their function can vary depending on life-stage, and therefore adaptive changes might tradeoff against each other in a developmental-stage dependent manner (Zera 2007, Flatt \& Heyland 2011, Gilbert et al. 2012, Oostra 2013). Taken together, my results support the notion that the diapausing phenotype can be achieved through different regulatory pathways in different species, which again supports the idea of different evolutionary backgrounds for dormancy stage development among taxa (see Ragland et al. 2010). Interestingly, the differences seem to be large even between species from the same order, such as insects.

Although the expansion speed has been rapid there are signs of range expansion slowing down towards in the north of the range. The results of this thesis suggest that the slowing down could relate to diapause behavior or cold tolerance. I found that the frequency of beetles which resurface after burrowing increased the longer the rearing photoperiod was, in all populations (study I). Resurfacing behavior was associated with increased winter mortality (study II, Lindström et al. unpublished). If long photoperiods induce stress-related behavior and mortality, it suggests that adapting to use a longer photoperiod as cue for diapause could be more difficult than adaptation to use shorter photoperiods, which might relate to the function of the molecular clock (Saunders 2002, Kauranen 2013). Combined with other, unpublished studies on cold tolerance, the data presented in this thesis also supports hypothesis of low winter temperatures retarding expansion (Valosaari et al. 2008). No significant correlation between large cold tolerance and population origin was detected. I did not find convincing evidence of a pre-diapause related increase in cold tolerance. The amount and profile of unsaturated fatty acids (homeoviscous adaptation, Sinensky 1974) and cold tolerance related HSP70 up-regulation (see Yocum 2001) remained relatively similar between the studied ages and states in diapause development (studies II, III). Previously it has been suggested that low levels of cold tolerance in the overwintering state (see Costanzo et al. 1997, 1998) are offset by the buffering effect of soil (Hsiao 1985). However, at high latitude, especially during times when temperature fluctuates around $0^{\circ} \mathrm{C}$, the water load in soil can rapidly increase and combined with sharp decreases in 
ambient temperature severe cold shocks can penetrate relatively deep into the soil, which could induce high mortality in overwintering L. decemlineata (Costanzo et al. 1997). The effects of climate change induced warming of winters (annual temperature increases are more pronounced during winter than summer, IPCC 2007) could therefore have a very high impact on the range expansion dynamics of this and other ectotherms overwintering in subterranean snow-buffered burrows (Leather et al. 1993).

My results suggest that the amount of inter-individual and -population variation and plasticity in life-history, stress tolerance and behavioral traits can be very large. This calls for a need of studies with integrated approaches to tease apart plastic from adaptive components and correlated responses from each other. This holistic approach could prove fruitful especially in studies which try to unravel the causal mechanisms behind adaptive variation in complex life-history traits with polygenic background such as diapause (Schmidt 2011).

To further investigate critical photoperiod classical backcross experiment where northern and southern beetles are mated within and between populations would further unravel the genetic basis of the trait. Furthermore this approach could reveal whether the genetic background of diapause incidence is similar to CPP. Since the molecular toolbox for L. decemlineata is increasing rapidly, new avenues of study are continuously opening (including the sequencing of the entire genome through the $15 \mathrm{~K}$ initiative; arthropodgenomes.org) (accessed 6.5.2013). For example hormonal manipulation of beetles and consequent large scale expression analysis (microarrays, RNAseq) or targeted studies of select candidate genes could increase our understanding of diapause ontogeny. It would for instance be interesting to probe more parts of the insulin signaling pathway, and utilize RNAi to suppress for instance FOXO in pre-diapause beetles, and then measure lipid content (Sim \& Denlinger 2008). In general, tissue specific expression patterns (especially of the fat body) would be important to produce a higher resolution image of gene expression patterns during diapause development. This also relates to the finding of good marker genes or traits which herald phase shifts in diapause development (Kostal 2006, Yocum et al. 2011).

To further validate topical application results (study IV) it would be important to determine $\mathrm{JH}$ titers and assess effectiveness of the $\mathrm{H} 17$ allatostatin mimic in vivo in L. decemlineata (e.g. JH biosynthesis rate, JH titer, ovarian developmental status). After validation of $\mathrm{H} 17$ it could prove to be an effective tool in experimental insect endocrinology to manipulate $\mathrm{JH}$ titers in a controllable dose-dependent manner (Kai et al. 2009). This is because negative manipulation of $\mathrm{JH}$ traditionally has been fairly difficult to perform without dramatic surgical procedures (such as the removal of the CA) (Gilbert 2012).

Lastly, to assess whether thermal stress is constraining further range expansion as suggested by my thesis (study II) and other studies (Boman et al. 2008, Valosaari et al. 2008, Lyytinen et al. 2009), a comparative cold tolerance physiology experiment is presently underway. Here two chrysomelid beetles (Agelastica alni and Chrysolina polita) found at high latitude have been 
investigated together with $L$. decemlineata. Importantly these two species have similar ecology as L. decemlineata, being oligophageous herbivores, which overwinter as adults burrowed into the soil. Preliminary results echo conclusions made in my thesis, that L. decemlineata possesses quite limited cold hardening options, and instead survival is based on an energetically favorable overwintering behavior and the capacity to burrow deep into the soil. 


\section{Acknowledgements}

The work presented in this thesis is a product of many minds and hands, and thanking all of them as much as they deserve would be beyond the scope of this page. Therefore I will only thank key persons who significantly have contributed to both the development of my research, and the development of me, as a researcher. First and foremost I thank my supervisors Leena Lindström and Anne Lyytinen for tireless suggestions and corrections which have been necessary during the last four years to poke me in the right direction. I will never forget the first meeting which we had in Leenas office 2009, where the thesis was planned (actually several theses were planned at the time, and thankfully only one pursued). Leena, you are a wonderful person, and I hope you will continue to inspire PhD students in the future as well! Together with Anne, Saija Piiroinen has provided a healthy dose of realism to summer plans, and stopped many a "pikku-koe" ("tiny-experiment") dead in its tracks. Thank you! It has been very rewarding and unproblematic to work in the Invasion Biology Group, especially with the added enthusiasm provided by excellent research assistants, especially Aigi Margus and Kati Kivisaari. I thank you all for providing a productive working atmosphere. And this spills over a general thanks to the department and our Ecology and Evolutionary biology section, which I find to be a place full of positive creative energy and nice people. I would also very much like to thank our stellar professors: Anneli Hoikkala, Janne Kotiaho, Johanna Mappes, Tapio Mappes, Mikko Mönkkönen and Hannu Ylönen for solid leadership and your approachable nature.

I have been most fortunate in being able to parasitize fully on Leenas research grants, knowing how much time many PhD students put on applying for grants, and wish to thank the Academy of Finland (and Leena!) for financing my whole $\mathrm{PhD}$ studies. The centers of Excellence in Evolution Research and Biological Interactions Research, Wihuri Foundation, Societas pro Fauna et Flora Fennica, the Biological Interactions Graduate School and Darwin Club are also thanked for providing logistic, intellectual and educational support during my thesis.

I think that the best part with research is the chance to collaborate with interesting persons. During my four years many experiments have been performed, and while some projects did not come into fruition, the interaction and discussions with fellow academics have always been rewarding. For data, ideas and inspiration I would like to thank Tuula Sinisalo, Reijo Käkelä, Vladimir Kostal, Päivi Uutela, Raimo Ketola, Tony Zera, Maaria Kankare, Sirpa Kaunisto, Tapio Mappes and Magnus Lindström. I thank Esa Koskela for entrusting the mantle of "responsible for lab animals" to me while he was in Canada, it was most rewarding! I would also like to thank my pre-examiners, Thomas Flatt and Karl Gotthard for taking the time to read through these pages and providing constructive feedback. Thomas is also thanked for very nice company during various meetings! I very much appreciate having Dan Hahn agreeing to be my opponent, you were my top choice. I again thank you for hosting us in Gainesville, I thoroughly enjoyed every bit of the visit! 
I will not thank my fellow PhD students (and postdocs) for "support during the difficult and desperate moments of the thesis..." since I feel that the $\mathrm{PhD}$ has not really been so desperate, rather I find that the last four years have been a blast, and this is in no small part thanks to you all! So thank you PhD student and postdoc friends from the Universities of Jyväskylä, Helsinki, Oulu, Joensuu and Turku for excellent company. We've shared many laughs. Special thanks go to the tireless organizers of Sauna and Support and to the coorganizers of EMPSEB18, and to Mika Mökkönen and Gaia Francini (+ il dottore!) for being real gems!

Finally I wish to thank my partner Eva, for listening to (or appearing to...) my tirades about various more or less irrelevant $\mathrm{PhD}$ related issues (such as problems with LC-MS/MS and JH III analyses) and for helping out, during more than one occasion, with the experiments. You are a very intelligent and thoroughly charming person, and I am truly fortunate to have you in my life! 


\title{
RESUMÉ (RÉSUMÉ IN SWEDISH)
}

\author{
Ekofysiologiska aspekter av anpassning till årstidsväxlingar: \\ Koloradoskalbaggens spridning i Europa
}

De flesta habitat på jorden finns i områden med årstidsväxlingar. Årstidsväxlingarna $i$ till exempel temperatur eller luftfuktighet följer förutsägbara geografiska mönster. I regel ökar årstidsväxlingarnas storlek med latitud (breddgrad), och är stora i den så kallade temperata zonen (som sträcker sig från latituder på $24^{\circ}$ till $67^{\circ}$ norr och söder om ekvatorn). Organismer som lever i omgivningar med stor variation i abiotiska (t.ex. temperatur) eller biotiska (t.ex. mängd parasiter) karaktärer är ofta anpassade till denna variation på olika sätt. De flesta organismer synkroniserar tillväxt och förökning med den tid på året då resurser finns som bäst tillhanda och förhållandena i övrigt är gynnsamma för tillväxt. Under perioder av stress har många organismer höjd stresstolerans. Många större djur som har möjlighet att välja sitt habitat migrerar både korta och längre sträckor efter näring, förökningsmöjligheter eller undan stressfulla förhållanden.

För anpassning till miljöer med stora årstidsväxlingar krävs att organismen vet vilken tid på året det är, alltså en kalender. Av de många varianter som existerar är den fotoperiodiska kalendern den vanligaste. Fotoperioden, alltså mängden ljus per dygn, följer ett väldigt specifikt mönster som relaterar till latitud. Runt ekvatorn är årstidsväxlingarna minimala, och vid polerna mycket stora. Den största orsaken till den fotoperiodiska kalenderns allmänhet är att förändringarna mellan år i fotoperiod är minimala. Därför kan en organism med så gott som fullständig säkerhet veta vilken tid på året det är genom att mäta mängden ljusa timmar per dygn.

När organismer förflyttas till nya områden, t.ex. för att de transplanterats med barlastvattnet i ett fartyg, kan de hamna i en omgivning där fotoperioden är annorlunda än i deras ursprungliga omgivning. Detta kan ha negativa följder om de tolkar tiden på året fel och t.ex. migrerar eller förökar sig under ofördelaktiga tider. Därför måste den fotoperiodiska kalendern justeras och synkroniseras med fotoperiodsväxlingarna i den nya omgivningen för att säkra överlevnad. Trots att det finns flera exempel på arter som spridit sig över stora områden under kort tid, finns ännu många öppna frågor om de ekologiska och evolutionära mekanismerna som ligger bakom både lyckad och misslyckad spridning.

I den här doktorsavhandlingen undersökte jag ekofysiologiska mekanismer bakom anpassning till ny fotoperiod och latitud $i$ en art som under en mycket kort tid, i ekologiska och i synnerhet evolutionära mått mätt, framgångsrikt har spridit sig över ett väldigt stort område. Arten i fråga är Koloradoskalbaggen (Leptinotarsa decemlineata), som ursprungligen härstammar från Mexiko men som under de senaste 150 åren har spridit sig till större delen av Nordamerika, Europa och djupt in i Asien. Koloradoskalbaggen hör till familjen Chrysomelidae, och är en oligofag herbivor som specialiserat sig på 
växter från familjen Solanacae. Alltså en lövskalbagge som äter växter från potatisväxtsläkten, dit flera viktiga odlingsväxter, som potatis, tomat och aubergine, hör. Koloradoskalbaggen har en komplicerad livscykel. Den vuxna baggen kan nämligen välja att endera föröka sig, eller alternativt, att spendera från ett par dagar till upp till 9 år i ett vilostadium. I områden med en vinter som är ofördelaktig för tillväxt och förökning väljer Koloradoskalbaggar som föds sent på sommaren i regel att övervintra i stället för att föröka sig. Detta betyder att de väger två risker mot varandra: risken att själv förgås under den kalla, långa vintern och således inte kunna föröka sig alls, mot risken att den avkomma de kunde producera på sensommaren inte hinner utvecklas och dör. Individer som förbereder sig för diapaus (en mycket djup och välprogrammerad form av vilostadium) bygger stora energireserver i form av triglycerider (fett), sänker sin metaboliska aktivitet, avstannar sin reproduktiva utveckling (ovarier degenerar och energin tas tillvara), samt söker upp passliga övervintringshabitat. Det sistnämnda innebär att vuxna baggar gräver sig ner i marken till djup på mellan 20 och $60 \mathrm{~cm}$, där de är väl skyddade från temperatur- och fuktighetsväxlingar på markytan. Beslutet att övervintra görs på basen av tre faktorer, av vilka den viktigaste är fotoperiod, åtföljd av temperatur och kvalitén på potatisen (som sjunker mot slutet av sommaren).

I min avhandling undersöker jag om europeiska koloradoskalbaggar har anpassat sig till årstidsväxlingarna i sina respektive lokala miljöer. De huvudsakliga karakterärna jag undersöker gäller sommarens längd, vinterns längd, den lokala fotoperioden, samt temperaturen under både sommaren och vintern. Högre latitud innebär kortare och kallare somrar, längre och kallare vintrar, samt större fluktuationer i temperatur under hela året. Dessa är väldigt betydande faktorer för små, växelvarma växtätare, som är tvungna att synkronisera sin livscykel med de lokala årstidsväxlingarna. Eftersom arten har spridit sig så snabbt genom Europa (på cirka 80 år) frågar jag om detta varit möjligt genom att arten a) är så passivt tolerant mot stress, b) har kunnat acklimatisera sig till väldigt varierande miljöer på grund av sin varierande livscykel (övervintringsbeteende) eller c) har kunnat anpassa sig genetiskt väldigt snabbt till de förändrande förhållandena (lokala anpassningar). Eftersom arten är invasiv (förflyttad på grund av mänsklig aktivitet) och alla Europas populationer härstammar från en liten grundarpopulation borde den genetiska variationen (grundmaterialet för evolution genom naturligt urval) vara begränsad. Låg genetisk variabilitet anses ofta bromsa eller till och med hindra att lokala anpassningar uppstår. Detta borde alltså vara ett hinder för alternativ c). Därutöver försöker jag ta ställning till möjliga mekanismer bakom observationer om en bromsning i spridning som kan ses vid de allra högsta latituderna.

Grundmetodologin som används är så kallade "gemensam trädgård" experiment ("common garden", kallas också för transplantationsexperiment) där skalbaggar samlats från flera populationer och hållits i ett laboratorium flera generationer (för att minska möjliga icke-genetiska effekter från de lokala omgivningarna). Deras avkomma används sedan i experiment där man efterapar de ursprungliga lokala omgivningarna. Om individer skiljer sig 
baserat på ursprungspopulation, och populationerna klarar sig bättre i förhållanden som motsvarar ursprungsomgivningen än de andra populationerna, tas det som ett starkt bevis på att populationen har anpassat sig lokalt till ursprungsomgivningen. Den enda faktorn jag manipulerade i omgivningen var fotoperioden. Eftersom dagarna blir ljusare under sensommaren ju högre latituden är, borde nordliga koloradoskalbaggar, såtillvida de är anpassade, förbereda sig för övervintring under längre fotoperiod än sydliga baggar.

Mina resultat visar entydigt att de europeiska populationerna har divergerat i flera viktiga aspekter av deras livscykel och fysiologi. De nordliga populationerna har accelererad individidutveckling samt förbereder sig för övervintring under betydligt längre fotoperiod än sydliga populationer (Studie I). Därutöver ökar diapausincidensen (den andel av populationen som övervintrar under väldigt kort fotoperiod) med latitud vilket antyder att hårdare vintrar i norra Europa har gallrat bort individer som inte övervintrar (som kunde överleva mildare vintrar t.ex. i Italien).

I den första studien användes endast beteende som parameter för diapaus (nedgrävd/på markytan), och därför undersökte jag i en ytterligare studie också underliggande fysiologi hos vuxna skalbaggar från två populationer, den sydligaste och nordligaste som använts i den första studien. Denna studie stödde resultaten från den första studien då stora fettreserver samlades i den nordliga populationen under både en kort och en lång fotoperiod, medan den sydliga populationen endast samlade stora fettreserver under den korta fotoperioden (Studie II). I den långa fotoperioden utvecklades däremot ovarierna hos honor från den sydliga populationen.

I studie II undersökte jag också om de övervintrande skalbaggarna har anpassat sig till låga temperaturer genom att öka mängden omättade fettsyror i deras cellmembraner och lipidlager. Ju mer omättade fettsyror, desto bättre kan lipider motstå att stelna vid låga temperaturer. Populations- eller fotoperiodsrelaterade skillnader i mättnadsgrad hittades däremot inte. Det här resultatet tyder på att en induktion av lipiders minskade mättnadsgrad inte hör till tidiga fasen av förberedelse för diapaus.

Dessa slutsatser fick stöd i en ytterligare studie (Studie III) där expression (aktivering) av diapausrelaterade gener (metaboliska, reglerande och stresstoleransrelaterade) undersöktes. Gener associerade med temperaturstresstolerans (HSP70-familjen) visade inte stark aktivering under förberedelserna för diapaus. Expressionsmönster i energimetaboliska gener lyfte fram att den nordliga populationen verkar förbereda sig för övervintring vid längre fotoperiod än den sydliga populationen och lyfte också fram att den nordliga populationen har en accelererad förberedelse för diapaus jämfört med den sydliga populationen.

Också expressionsmönster hos flera gener som har föreslagits vara viktiga för den fysiologiska induktionen av diapaus undersöktes i studie III. Jag var intresserad om dessa visade skillnader mellan populationerna som kunde antyda involvering i anpassningsprocessen. Dylika bevis hittades inte. En liknande frågeställning låg bakom den fjärde studien, där skalbaggar från tre 
populationer manipulerades med ämnen som på påverkar den hormonala regleringen av diapaus. Trots att manipulationen lyckades kunde vi inte se skillnader mellan populationerna i hormonreceptivitet, vilket kan tolkas som indirekt bevis på att den hormonella regleringen av diapaus inte har divergerat trots att andra egenskaper har gjort det. En trolig förklaring är pleiotropa eller motsatta effekter av hormoner i fysiologiska system (Studie IV). Det vill säga, förändring i ett system som har positiv effekt på individens fitness kan vägas upp med negativa effekter i ett annat fysiologiskt system.

I den sista studien undersöktes variation i beteende samt korrelationsmönster på individnivå i fettreservstorlek, diapausbeteende samt metabolisk aktivitet. Resultaten stärker tidigare studier vad gäller fotoperiodism samt diapausontogeni; den nordligare populationen verkar ha en inte bara accelererad, utan också energieffektivare föreberedning för diapaus (Studie V). Resultaten tyder också på skillnader mellan populationerna i hur starkt nordliga och sydliga populationer förbereder sig. Medan alla skalbaggar från den nordliga populationen som visade diapausbeteende hade stora fettreserver hade skalbaggarna från den sydliga populationen mycket mer variation i associationen mellan beteende och energireserver. Det vill säga, de kunde visa diapausbeteende trots att de inte var förberedda för övervintring. Det är nämligen möjligt att dessa icke förberedda individer skulle överleva i de mildare förhållandena under vintern i södra Europa där stora energireserver kanske inte skulle behövas.

Som slutsats verkar det som om den explosionsartade spridningen av koloradoskalbaggen i Europa är associerad med adaptiv synkronisering av flera egenskaper som relaterar till fenologi och metabolisk stresstolerans (Studie I, II, III, IV). Mina resultat stöder därför slutsatser som dragits nyligen i flera studier, nämligen att fotoperiodisk anpassning är en viktig del av dynamiken som styr arters utbredning och spridning. Det är en viktig aspekt att beakta då inflytandet av klimatförändring på invasiva arters (t.ex. sjukdomsalstrare) invasionspotential undersöks, eftersom det verkar som flera djur kan anpassa sig snabbt till förändrad fotoperiod.

Vad gäller artens fortsatta spridning norrut så tyder resultaten från studie II, III, $\mathrm{V}$ samt opublicerade experiment, att $L$. decemlineata har ett relativt begränsat urval biokemiska och fysiologiska metoder som buffrar mot temperaturstress. En stor orsak till artens framgång hittills är därför snarare det välbuffrade övervintringsmikrohabitatet, än artens egen stresstolerans. I och med stora energilager kan individer med liten risk vänta ut långa vintrar för att sedan maximera reproduktion och tillväxt under en kort men intensiv period under sommaren. Vid väldigt hög latitud blir temperatur-stressen däremot så hög att fysiologiska anpassningar blir behövliga (som ses i de flesta insekter som lever i subarktiska och arktiska förhållanden). Därför kan slutsatsen dras att artens låga köldtolerans troligen är en bidragande faktor till att spridningen saktat ner. 


\title{
YHTEENVETO (RÉSUMÉ IN FINNISH)
}

\author{
Ekofysiologisia sopeumia vuodenaikaisvaihteluun: Koloradonkuoriaisen \\ leviäminen Euroopassa
}

Suurin osa maapallon elinympäristöistä sijaitsee alueilla, joissa useat ympäristötekijät, kuten lämpötila ja ilmankosteus, vaihtelevat vuodenajan mukaan. Näiden nk. vuodenaikaisvaihtelujen voimakkuus riippuu maantieteellisestä sijainnista. Vuodenaikaisvaihteluiden voimakkuus lisääntyy siirryttäessä päiväntasaajalta napoja kohti. Vuodenaikaisvaihtelut ovat tavanomaisesti voimakkaimpia lauhkealla vyöhykkeellä $\left(24-67^{\circ} \mathrm{N}\right)$. Ympäristöissä, joissa abioottisten (esim. lämpötilan) tai bioottisten (esim. loispaineen) tekijöiden vuodenaikaisvaihtelu on voimakasta, eliöiden on täytynyt sopeutua tähän vaihteluun. Jotta eliöiden kasvu ja lisääntyminen onnistuisivat, eliöt ajoittavat lisääntymisen ja kasvun siihen vuodenaikaan, jonka aikana resursseja on eniten saatavilla ja olosuhteet ovat muutoinkin suotuisat kasvulle. Monet isokokoiset eläimet voivat myös siirtyä lyhyitä tai pitkiä matkoja alueelta, jossa olosuhteet ovat muuttuneet epäsuotuisiksi, alueille, joissa on riittävästi ravintoa ja muita resursseja. Toinen tapa välttää ympäristöstressiä, esim. alhaisia lämpötiloja, on lisätä stressinsietokykyä. Jotta eliö voi ajoittaa nämä muutokset käyttäytymisessään ja fysiologiassaan, sen on pystyttävä luotettavasti "ennustamaan" tuleva vuodenajan etenemisestä johtuva ympäristön muutos. Luotettava signaali, joka ei muutu vuosien välillä ja joka on spesifinen kullekin leveysasteelle, on päivänpituus ja sen muutokset. Useat eliöt käyttävätkin kasvun ja lisääntymisen ajoittamisessa hyväkseen valojakson muuttumista ja mittaavat vuorokauden valoisan ajan pituutta.

Kun eliö kulkeutuu, esimerkiksi laivan painolastiveden mukana, uudelle alueelle, alueen valojakso voi olla erilainen kuin eliön alkuperäisessä elinympäristössä. Tällöin eliö voi erehtyä vuodenajasta ja esimerkiksi lisääntyä epäsuotuisaan aikaan vuodesta. Jotta eliö voisi sopeutua uusiin olosuhteisiin, sen fotoperiodisen kalenterin täytyy muuttua. Vaikka useiden lajien tiedetään levinneen lyhyessä ajassa laajoille alueille, monet uuteen elinympäristöön sopeutumiseen liittyvät ekologiset ja evoluutiobiologiset mekanismit ovat vielä hämärän peitossa.

Tutkin väitöskirjassani ekofysiologisia mekanismeja, jotka liittyvät sopeutumiseen uuteen valojaksoon ja kasvukauden pituuteen. Tutkimuslajina oli koloradonkuoriainen (Leptinotarsa decemlineata), joka on levittäytynyt ekologisesti ja varsinkin evolutiivisessa mielessä lyhyessä ajassa laajalle alueelle. Koloradonkuoriainen on kotoisin Meksikosta, josta se on viimeisten 150 vuoden aikana levinnyt ihmisen siirtämänä Pohjois-Amerikkaan, suureen osaan Eurooppaan ja syvälle Aasiaan. Koloradonkuoriainen on oligofaaginen herbivori, joka on erikoistunut syömään Solanacae-heimon kasveja. Tähän heimoon kuuluvat monet taloudellisesti tärkeät kasvit, kuten peruna, tomaatti, paprika ja munakoiso. Koloradonkuoriaisen elinkiertoon kuuluu aktiivisuus- ja lepojaksot. Aikuinen 
kuoriainen voi joko lisääntyä tai vaipua lepotilaan, joka kestää parista päivästä jopa 9 vuoteen. Jos kuoriainen aikuistuu myöhään kesällä, jolloin sen jälkeläiset eivät todennäköisesti ehtisi kehittyä aikuiseksi ennen talven alkamista, se jättää lisääntymisen väliin ja alkaa valmistautua talvehtimiseen. Koloradonkuoriaiset talvehtivat passiivisessa, horrosta syvemmässä ja geneettisesti määräytyvässä lepovaiheessa, diapaussissa. Jotta talvehtiminen onnistuisi, koloradonkuoriaiset valmistautuvat siihen monin tavoin. Diapaussiin valmistautuvat yksilöt mm. kasvattavat energiavarastoja varastoimalla triglyseridejä ja alentavat perusaineenvaihduntansa tasoa vähentääkseen energiankulutusta. Lisäksi niiden sukupuolirauhaset muuttuvat inaktiivisiksi (ovariot surkastuvat ja niissä oleva energia otetaan talteen). Lopulta koloradonkuoriaiset siirtyvät sopiville talvehtimispaikoille. Talvehtimispaikassa kuoriaiset kaivautuvat maahan $20-60 \mathrm{~cm}$ syvyyteen, jossa ne ovat suojassa maan pinnalla tapahtuvista nopeista lämpötilan ja kosteuden muutoksilta. Diapaussin alkamiseen vaikuttavat kolme ympäristötekijää, joista tärkein on valojakso. Myös lämpötila ja ravinnon laatu vaikuttavat käyttäytymiseen.

Väitöskirjatyössäni tutkin, ovatko eurooppalaiset koloradonkuoriaiset sopeutuneet elinalueensa ympäristötekijöiden vuodenaikaisvaihteluihin (paikallissopeuma), ja mitkä tekijät voisivat selittää lajin kyvyn asuttaa laajoja maantieteellisiä alueita. Tutkimiani ympäristötekijöitä olivat kasvukauden pituus, talven pituus, valojakso ja lämpötila. Kaikki nämä ympäristötekijät muuttuvat siirryttäessä maantieteelliseltä alueelta toiselle. Mitä pohjoisemmaksi mennään, sitä lyhyempiä ja kylmempiä kesät ovat ja toisaalta sitä pitempiä ja kylmempiä talvet ovat. Pohjoista kohden myös lämpötilojen vuotuiset vaihtelut suurenevat. Edellä mainitut tekijät vaikuttavat merkittävästi pienen vaihtolämpöisen kasvinsyöjän selviytymiseen, jonka täytyy synkronisoida elinkiertonsa paikalliseen vuodenaikaisvaihteluun. Selvitin väitöskirjassani mekanismeja, jotka ovat voineet mahdollistaa koloradonkuoriaisen nopean (noin 80 vuodessa tapahtuneen) leviämisen etelästä pohjoiseen Euroopan läpi. Mahdollisia selityksiä ovat a) korkea perustason stressinsietokyky, b) vaihteleva elinkierto (aktiivisuus- ja lepojakson vaihtelu), jolloin akklimatisaatio vaihteleviin ympäristöihin on mahdollista tapahtua nopeasti ja c) lajin hyvin nopea sopeutumiskyky paikallisiin olosuhteisiin (adaptaatio). Koska Euroopan populaatiot ovat peräisin pienestä, 1920-luvulla Ranskaan tulleesta populaatiosta, populaatioiden geneettisen vaihtelun tulisi olla pientä. Alhaisen geneettisen vaihtelun oletetaan yleensä hidastavan ja jopa estävän sopeutumisen uusiin olosuhteisiin, koska luonnonvalinnalla ei ole raaka-ainetta. Lisäksi tutkin, mikä mekanismi voisi selittää Pohjois-Euroopan pohjoisosissa havaitun koloradonkuoriaisen leviämisen hidastumisen.

Väitöskirjan kokeita varten koloradonkuoriaisia kerättiin perunapelloilta useista populaatioista ja tuotiin laboratorioon, jossa niitä kasvatettiin vähintään kahden sukupolven ajan ennen kokeiden aloittamista. Näin haluttiin minimoida mahdolliset emon ilmiasun vaikutukset jälkeläisten ilmiasuun (äitivaikutukset). Eri populaatioiden kuoriaisia kasvatettiin olosuhteissa, jotka vastasivat Pohjois- ja Etelä-Euroopan olosuhteita (englanniksi "common garden"). Jos po- 
pulaatiot ovat sopeutuneet ympäristönsä olosuhteisiin, niiden tulisi menestyä suhteellisesti paremmin oman alueensa olosuhteissa kuin muut populaatiot. Nämä suhteelliset erot menestymisessä viittaisivat paikallissopeumaan. Erityisesti selvitin, aloittavatko populaatiot talvehtimisen eri valojaksoissa. Loppukesän päivänpituus pohjoisessa on pidempi kuin vastaavaan aikaan etelässä. Jos pohjoiseurooppalaiset koloradonkuoriaiset ovat sopeutuneet pohjoisen valojaksoon ja lyhyeen kesään, niiden tulisi aloittaa talvehtimiseen valmistautuminen pidemmässä päivänpituudessa kuin eteläiset yksilöt, jotta ne ehtisivät talvehtimaan ennen talven alkamista.

Tulokseni osoittivat selvästi, että eurooppalaisten koloradonkuoriaisten monet elinkiertopiirteet ja fysiologiset ominaisuudet ovat sopeutumia ympäristönsä olosuhteisiin. Pohjoisten populaatioiden yksilönkehitys oli nopeampi ja yksilöt valmistautuivat talvehtimaan huomattavasti pidemmässä päivänpituudessa kuin eteläisemmät populaatiot (osakoe I). Tämän lisäksi niiden yksilöiden osuus, jotka aloittivat diapaussin lyhyessä päivänpituudessa, kasvoi pohjoista kohden. Tulos viittaa siihen, että ankarat pohjoisen talvet ovat karsineet pois yksilöitä, jotka eivät talvehdi.

Ensimmäisessä osakokeessa määritin diapaussin aloittamisen koloradonkuoriaisen käyttäytymisen perusteella (kaivautunut/ei kaivautunut maahan), mutta en ottanut huomioon yksilöiden fysiologisia muutoksia. Osakokeessa II tutkin, onko talvehtimaan valmistautuvien eteläisen ja pohjoisen populaatioiden yksilöiden välillä fysiologisia eroja. Kuten osakokeessa I, myös kokeessa II havaittiin paikallissopeuma. Eteläisen populaation kuoriaiset kasvattivat energiavarastoja (rasvojen määrää) ainoastaan lyhyessä päivänpituudessa, kun taas pohjoisen populaation kuoriaiset varastoivat rasvaa myös hyvin pitkässä päivänpituudessa. Lisäksi sukurauhasten kehittymisessä oli eroja populaatioiden välillä. Pitkässä päivänpituudessa ainoastaan eteläisen populaation naaraiden ovaariot kehittyivät isoiksi. Tässä tutkimuksessa tutkin myös, ovatko talvehtivat kuoriaiset sopeutuneet kylmään lisäämällä solukalvon tyydyttymättömien rasvahappojen määrää. Tällöin solukalvot pysyvät toimivina myös alhaisissa lämpötiloissa lisäten kuoriaisen kylmänkestävyyttä.aikana. Koska en havainnut eroja lipidimuutoksissa populaatioiden tai valojaksojen välillä, muutokset lipideissä eivät näyttäisi oleva osa lisääntynyttä lämpötilastressinsietokykyä talvehtimaan valmistautuvissa koloradonkuorisissa. Tätä johtopäätöstä tukee kolmas osatyö, jossa tutkin diapaussin liittyvien metabolisten, säätely- ja stressinsietokykygeenien aktivoitumista ja ilmenemistä (osakoe III). HSP70perheeseen kuuluvat stressinsietokykygeenit eivät aktivoituneet vahvasti diapaussiin valmistautumisen aikana. Kuten muissa aikaisemmissa tutkimuksissa on havaittu, monet energiametaboliaan liittyvät geenit ilmenivät pohjoisessa populaatiossa hyvin pitkässä päivänpituudessa ja eteläisessä populaatiossa ainoastaan lyhyessä päivänpituudessa. Tutkimukseni osoitti myös, että pohjoisen populaation yksilöiden valmistautuminen talveen on nopeampaa verrattuna eteläiseen populaatioon, mikä on sopeuma pohjoisen Euroopan lyhyeen kasvukauteen. 
Kolmannessa osakokeessa tutkin useita ns. kandidaattigeenejä, joilla on esitetty olevan tärkeä rooli diapaussissa olevien yksilöiden fysiologian säätelyssä tai diapaussin aloittamisessa. Tulokset eivät tukeneet hypoteesia siitä, että havaitut muutokset eri maantieteellisiltä alueilta peräisin olevien koloradonkuoriaisten diapaussissa olisivat tapahtuneet näissä geeneissä. Tätä johtopäätöstä tuki myös osakokeen IV tulokset. Siinä manipuloin diapaussiin liittyvien hormonien pitoisuuksia aikuisissa koloradonkuoriaisissa, jotka olivat kolmesta populaatiosta. Hormonien manipulaation vaikutukset eivät eronneet populaatioiden välillä. Siten tulokset eivät viitanneet siihen, että muutokset diapaussissa (siten sopeutuminen) olisivat tapahtuneet diapaussiin liittyvissä hormonaalisissa säätelyreiteissä. Yksi mahdollinen selitys populaatioiden välisten erojen puuttumiselle on, että hormoneilla on pleiotropisia tai vastavaikutteisia vaikutuksia fysiologisissa järjestelmissä. Hormoni saattaa siten muuttaa yksilön kelpoisuutta vaikuttamalla myönteisesti johonkin fysiologiseen ominaisuuteen ja samanaikaisesti negatiivisesti johonkin toiseen ominaisuuteen. Viimeisessä tutkimuksessa (osakoe V) kiinnostuksen kohteena oli diapaussikäyttäytyminen eli maahan kaivautuminen: korreloiko yksilön käyttäytyminen lipidivarastojen koon ja/tai aineenvaihdunnan tason kanssa. Tulokset tukivat aikaisempia johtopäätelmiä. Pohjoinen populaatio ei ainoastaan valmistaudu talvehtimaan pidemmässä päivänpituudessa kuin eteläisempi, vaan myös tekee sen nopeammin ja energiatehokkaammin. Tässä tutkimuksessa havaittiin myös populaatioiden välisiä eroaja siinä, miten vahvasti kaivautumiskäyttäytyminen on liittynyt fysiologisiin ominaisuuksiin. Niillä pohjoisen populaation koloradonkuoriaisilla, jotka kaivautuivat maahan, oli isot rasvavarastot verrattuna niihin yksilöihin, jotka pysyivät maan pinnalla. Sen sijaan eteläisen populaation kuoriaisilla maahan kaivautumisen ja rasvavaraston koon välillä ei ollut selkeää riippuvuussuhdetta. Tämä viittaa siihen, että eteläiset kuoriaiset saattavat kaivautua maahan talvehtimaan, vaikka ne eivät ole fysiologisesti valmiita talvehtimaan. Ne kuitenkin saattavat selvitä Etelä-Euroopan talven yli, jossa talvehtimisaika on lyhyt eivätkä ne siten tarvitse isoja energiavarastoja.

Tutkimukseni tulokset viittaavat siihen, että koloradonkuoriaisen räjähdysmäinen leviäminen Euroopassa on ollut mahdollista, koska monet fenologiaan ja stressitoleranssiin liittyvät ominaisuudet ovat nopeasti muuttuneet vastaamaan uuden ympäristön olosuhteita (osatyöt I, II, III, IV). Toisaalta koloradonkuoriaisen leviämistä yhä pohjoisemmaksi rajoittavat osaltaan lajin rajoittunut kyky reagoida alhaiseen lämpötilaan biokemiallisesti ja fysiologisesti (osatyöt II, III, V, ei-julkaistut tutkimukset). Stressinsietokyvyn sijasta yksi merkittävä selitys, miksi laji on onnistuneesti levinnyt kylmillekin alueille, on lajin talvehtimiskäyttäytyminen. Yksilöt talvehtivat kaivautuneena maahan, jossa ne ovat suojassa lämpötilojen vaihteluilta ja pakkaselta. Isojen, ennen talvehtimista kerättyjen energiavarastojen turvin ne selviävät pitkästäkin talvesta ja ovat valmiita aloittamaan lisääntymisen heti seuraavana kasvukautena. Hyvin pohjoisessa routa voi tunkeutua myös syvälle maahan ja tavoittaa maassa talvehtivat koloradonkuoriaiset. Koska koloradonkuoriaisen kylmätoleranssi on heikko, on tämä saattanut aiheuttaa pohjoiseen leviämisen hidastumisen. 
Väitöskirjani tulokset tukevat aikaisempien tutkimusten johtopäätöksiä siitä, että fotoperiodinen sopeutuminen on erittäin tärkeä osa evoluutioekologista dynamiikkaa, joka ohjaa lajien leviämistä ja vaikuttaa levinneisyysalueen rajoihin. Valojaksoisuus (fotoperiodismi) tulisi sisällyttää tutkimuksiin, joissa tutkitaan ilmastonmuutoksen vaikutuksia tulokas- ja vieraslajien (esimerkiksi tuholaislajien tai loisten) levinneisyysalueiden muutoksiin. Eliön kyky sopeutua muuttuneeseen valojaksoon saattaa mahdollistaa sen, että eliöt menestyvät alueilla, joilla muihin ympäristötekijöihin, kuten lämpötilaan, perustuvien ennusteiden mukaan niiden ei tulisi pystyä menestymään. Jos tätä ei huomioida, ennusteet eliöiden levinneisyysalueiden muutoksista voivat olla virheellisiä. 


\section{REFERENCES}

Abrams P.A., Leimar O., Nylin S. \& Wiklund C. 1996. The effect of flexible growth rates on optimal sizes and development times in a seasonal environment. Am. Nat. 147: 381-395.

Addo-Bediako A., Chown S.L. \& Gaston. K.J. 2000. Thermal tolerance, climatic variability and latitude. Proc. R. Soc. B. 267: 739-745.

Addo-Bediako A., Chown S.L. \& Gaston, K.J. 2002. Metabolic cold adaptation in insects: a large-scale perspective. Funct. Ecol. 16: 332-338.

Alyokhin A.V. 2009. Colorado potato beetle management on potatoes: current challenges and future prospects. Fruit, Vegetable and Cereal Science and Biotechnology 3: 10-19.

Alyokhin A.V. \& Ferro D.N. 1999. Reproduction and dispersal of summergeneration Colorado potato beetle (Coleoptera: Chrysomelidae). Environ. Entomol. 28: 425-430.

Angiletta M.J., Steury, T.D. \& Sears, M.W. 2004. Temperature, growth rate and body size in ectotherms: fitting pieces of a life-history puzzle. Integr. Comp. Biol. 44: 498-509.

Arnqvist G. \& Rowe L. 2005. Sexual conflict. Princeton University Press, New Jersey.

Arrese E.L. \& Soulages J.L., 2010. Insect fat body: energy, metabolism, and regulation. Annu. Rev. Entomol. 55: 207-225.

Atkinson D. \& Sibly R.M. 1997. Why are organisms usually bigger in colder environments? Making sense of a life history puzzle. Trends Ecol. Evol. 12: 235-239.

Bale J.S. \& Hayward S.A.L. 2010. Insect overwintering in a changing climate. J. Exp. Biol. 213: 980-94.

Beck S.D. \& Hanec W. 1960. Diapause in the European corn borer, Pyrausta nubialis (Hübn.). J. Insect Physiol. 4: 304-318.

Beekman M., van Stratum P. \& Lingeman R. 1998. Diapause survival and postdiapause performance in Bumblebee queens (Bombus terrestris). Entomol. Exp. Appl. 89: 207-214.

Berg J.M., Tymoczko J.L. \& Stryer L. (eds.) 2002. Biochemistry. W.H. Freeman and Company, New York.

Bergmann C. 1847. Über die Verhältnisse der Wärmeökonomie der Thiere zu ihrer Grösse. Göttinger Studien 3: 595-708.

von Bertalanffy L. 1960. Principles and theory of growth. In: Nowinski, W.N. (ed.) Fundamental aspects of normal and malignant growth. Elsevier Press, Amsterdam.

Blanckenhorn W.U. \& Demont M. 2004. Bergmann and converse Bergmann latitudinal clines in arthropods: two ends of a continuum? Integr. Comp. Biol. 44: 413-424.

Bligh E.G. \& Dyer W.J. 1959. A rapid method of total lipid extraction and purification. Can. J. Biochem. Physiol. 37: 911-917. 
Block W. 1990. Cold tolerance of insects and other arthropods. Phil. Trans. R. Soc. Lond. B. 326: 613-633.

Boman S., Grapputo A., Lindström L., Lyytinen A. \& Mappes J. 2008. Quantitative genetic approach for assessing invasiveness: geographic and genetic variation in life-history traits. Biol. Invasions. 10: 1135-1145.

Bradshaw W.E. \& Holzapfel C.M. 2001. Genetic shift in photoperiodic response correlated with global warming. Proc. Nat. Acad. Sci. USA. 98: 14509-14511.

Bradshaw W.E. \& Holzapfel C.M. 2007. Evolution of animal photoperiodism. Ann. Rev. Ecol. Evol. Syst. 3: 1-25.

Bradshaw W.E. \& Holzapfel C.M. 2010. In: Denlinger D.L. \& Lee R. E. (eds.), Low temperature biology of insects. Cambridge University Press, Cambridge.

Bradshaw W.E., Quebodeaux, M.C. \& Holzapfel C.M. 2001. Circadian rhythmicity and photoperiodism in the pitcher-plant mosquito: adaptive response to the photic environment or correlated response to the seasonal environment? Am. Nat. 161, 735-746.

Bradshaw W.E., Holzapfel C.M. \& Mathias D. 2006. Circadian rhythmicity and photoperiodism in the pitcher-plant mosquito: can the seasonal timer evolve independently of the circadian clock? Am. Nat. 167: 601-605.

Bresser A.H.M. et al. 2005. The effects of climate change in the Netherlands. Netherlands Environmental Agency Report 773001037. ISBN: 9069601362.

Brower L.P., Calvert W.H., Hedrick L.E. \& Christian J. 1977. Biological observations on an overwintering colony of Monarch butterflies (Danaus plexippus, Danaidae) in Mexico. J. Lepid. Soc. 31: 232-242.

Bünning E. 1936. Die endogene Tagesrhythmik als Grundlage der Photoperiodishen Reaktion. Berichte der Deutschen Botanischen Geschellschaft 53: 590-607.

Canavoso L.E., Jouni Z.E., Karnas K.J., Pennington J.E. \& Wells M.A. 2001. Fat Metabolism in Insects. Annu. Rev. Nutr. 21: 23-46.

Casagrande R.A. 1987. The Colorado potato beetle: 125 years of mismanagement. Bull. Entomol. Soc. Am. 33: 142-150.

Chown S. \& Gaston K. 1999. Exploring links between physiology and ecology at macro-scales: the role of respiratory metabolism in insects. Biol. Rev. 74: 87120.

Chown S.L. \& Klok C.J. 2003. Altitudinal body size clines: Latitudinal effects associated with changing seasonality. Ecography 26: 445-455.

Chown S.L. \& Nicholson S.W. 2004. Insect physiological ecology - mechanisms and patterns. Oxford University Press, Oxford.

Clarke A. 1993. Seasonal acclimatization and latitudinal compensation in metabolism: do they exist? Funct. Ecol. 7: 139-149.

Costanzo J.P., Moore J.B, Lee R.E., Kaufman P.E. \& Wyman J.A. 1997. Influence of soil hydric parameters on the winter cold hardiness of a burrowing beetle, Leptinotarsa decemlineata (Say). J. Comp. Physiol. B. 167: 169-176.

Costanzo J.P., Humphreys T.L., Lee RE., Moore J.B., Lee M.R. \& Wyman J.A. 1998. Long-term reduction of cold hardiness following ingestion of ice- 
nucleating bacteria in the Colorado potato beetle, Leptinotarsa decemlineata. J. Insect Physiol. 44: 1173-1180.

Cox R.T. \& Carlton C.E. 1988. Paleoclimatic influences in the evolution of periodical cicadas (Insecta: Homoptera: Cicadiae: Magicicada spp.). Am. Midl. Nat. 120: 183-193.

Dalin P., Bean D.W., Dudley T.I., Carney V.A., Eberts D., Gardner K.T., Herbertson E., Jones E.N., Kazmer D.J., Michels G.J., O'Meara S.A. \& Thompson D.C. 2010. Seasonal adaptations to day length in ecotypes of Diorhabda spp. (Coleoptera: Chrysomelidae) inform selection of agents against saltscedars (Tamarix spp.) Environ. Entomol. 39: 1666-1675.

Danilevski A.S. 1965. Photoperiodism and seasonal development of insects. Oliver and Boyd, London.

Danilevski A.S., Goryshin N.I. \& Tyshechen V.P. 1970. Biological rhythms in terrestrial arhtropods. Annu. Rev. Entomol. 15: 201-244.

Danks H.V. 1987. Insect dormancy: an ecological perspective. Biological Survey of Canada (Terrestrial Arthropods), Ottawa. Biological Survey of Canada Monograph Series No. 1.

Danks H.V. 2000. Dehydration in dormant insects. J. Insect Physiol. 46: 837-852.

Danks H.V. 2007. The elements of seasonal adaptations in insects. Can. Entomol. 139: 1-44.

Denlinger D.L. 2002. Regulation of diapause. Annu. Rev. Entomol. 47: 93-122.

Denlinger D.L. \& Lee R.E. 2010. Low temperature biology of insects. Cambridge University Press, Cambridge.

van Dooremalen C., Roel P. \& Ellers J. 2009. Maximised pufa measurements improve insight in changes in fatty acid composition in response to temperature. Arch. Insect Biochem. Physiol. 72: 88-104.

Dmitriew C.M. 2011. The evolution of growth trajectories: what limits growth rate? Biol. Rev. 86: 97-116.

Duckworth R.A. 2009. The role of behavior in evolution: a search for mechanism. Evol. Ecol. 23: 513-531.

Egevang C., Stenhouse I.J., Phillips R.A., Petersen A., Fox J.W. \& Silk. J.R.D. 2010. Tracking of Arctic terns Sterna paradisaea reveals longest animal migration. Proc. Nat. Acad. Sci. USA. 10.1073.

Elton C.S. 1958. The ecology of invasions by animals and plants. Melthuen \& Co, London.

EPPO 2006. Distribution maps of quarantine pests for Europe, Leptinotarsa decemlineata. ADAS, Nottingham, UK. Available at: http:/ / pqr.eppo.org/datas/LPTNDE/LPTNDE.pdf

Fauvergue X., Vercken E., Malausa T. \& Hufbauer R.A. 2012. The biology of small, introduced populations, with special reference to biological control. Evol. Appl. 5: 424-443.

Feder J.H., Rossi J.M., Solomon J., Solomon N. \& Lindquist S. 1992. The consequences of expressing hsp70 in Drosophila cells at normal temperatures. Genes Dev. 6: 1402-1413. 
Feder M.E. \& Hoffmann G.E. 1999. Heat-shock proteins, molecular chaperones, and the stress response: evolutionary and ecological physiology. Апnи. Rev. Physiol. 61: 243-282.

Flatt T. \& Heyland A. (eds.) 2011. Mechanisms of life history evolution, Oxford Biology, New York.

Folch J., Lees M. \& Sloane Stanley G.H. 1957. A simple method for the isolation and purification of total lipids from animal tissue. J. Biol. Chem. 226: 497509.

Fritzén N.R. \& Koponen S. 2011. The cave spider Meta menardi (Araneae, Teragnathidae) - occurrence in Finland and notes on its biology. Memoranda Soc. Fauna Flora Fennica 87: 80-86.

Gabel F., Pusch M.T., Breyer P., Burmester V., Walz N. \& Garcia X. 2011. Differential effect of wave stress on the physiology and behaviour of native versus non-native benthic Invertebrates. Biol. Invasions. 13: 18431853.

Gaston K. 2003. The structure and dynamics of geographic ranges. Oxford Series in Ecology and Evolution, Oxford.

Gilbert L.G. 2012. Insect endocrinology. Academic Press, Elsevier, London.

Goles E., Schulz O. \& Markus M. 2001. Prime number selection of cycles in a predator-prey model. Complexity 6: 33-38.

Gomi T. 2007. Seasonal adaptations of the fall webworm Hypantria cunea (Drury) (Lepidoptera:Arctiidae) following its invasion of Japan. Ecol. Res. 22: 855-861.

Goryshin N.I., Volkovich T.V., Saulich A.K. \& Shakhova N.N. 1987. Comparative- ecological study of Colorado potato beetle, Leptinotarsa decemlineata Say (Coleoptera, Chrysomelidae) populations of the European part of the USSR. Entomological Review 60: 131-142.

Goto S.G. \& Kimura M.T. 1998. Heat- and cold-shock responses and temperature adaptations in subtropical and temperate species of Drosophila. J. Insect Physiol. 44: 1233-1239.

Gotthard K., Nylin S. \& Wiklund C. 1999. Seasonal plasticity in two satyrine burreflies: state-dependent decision making in relation to daylength. Oikos 84: 453-462.

Graham L.A., Bendena W.G. \& Walker V.K. 1996. Juvenile hormone regulation and developmental expression of a Tenebrio desiccation stress protein gene. Dev. Genet. 18: 296-305.

Grodzicki P. \& Walentynowicz K. 2011. Hypometabolism in insects. In: Hypometabolism: Strategies of Survival in Vertebrates and Invertebrates. Research Signpost, Ontario.

Grotewiel M.S., Martin I., Bhandari P. \& Cook-Wiens E. 2005. Functional senescence in Drosophila melanogaster. Ageing Res. Rev. 4: 372-397.

Guppy M. \& Withers P. 1999. Metabolic depression in animals: physiological perspectives and biochemical generalizations. Biol. Rev. 74: 1-40.

Hack M.A. 1997. The effects of mass and age on standard metabolic rate in house crickets. Physiol. Entomol. 22: 325-331. 
Hahn D.A. \& Denlinger D.L. 2007. Meeting the energetic demands of insect diapause: Nutrient storage and utilization. J. Insect Physiol. 53: 760-773.

Hahn D.A. \& Denlinger D.L. 2011. Energetics of insect diapause. Annu. Rev. Entomol. 56: 103-121.

Haldane J.B.S. 1949. Suggestions as to quantitative measurement of rates of evolution. Evolution 3, 51-56.

Hanshew B.A. \& Garcia T.S. 2012. Invasion of the shelter snatchers: behavioural plasticity in invasive red swamp crayfish, Procambarus clarkii. Freshwater Biol. 57: 2285-2296.

Hanski I. 1988. Four kinds of extra long diapause in insects: A review of theory and observations. Ann. Zool. Fennici. 25: 37-53.

Harms C.A. \& Turingan R.G. 2012. Dietary flexibility despite behavioral stereotypy contributes to successful invasion of the pike killifish, Belonesox belizanus, in florida, USA. Aquat. Invasions 7: 547-553.

Hazel J.R. 1995. Thermal adaptation in biological membranes: Is homeoviscous adaptation the explanation? Annu. Rev. Physiol. 57: 19-42.

Heikinheimo M. \& Fougstedt B. 1992. Statistics of soil temperature in Finland. Meteorol. Publ. 22: 1-75.

Hiesaar K., Metspalu L., Jõudu J. \& Jõgar J. 2006. Over-wintering of the Colorado potato beetle (Leptinotarsa decemlineata Say) in field conditions and factors affecting its population density in Estonia. Agron. Res. 4: 21-30.

Hochachka P.W. \& Somero G.N. (eds.) 2002. Biochemical adaptation: Mechanism and process in physiological evolution. Oxford University Press, New York.

Hodkinson I.D. 2003. Metabolic cold adaptation in arthropods: a smaller-scale perspective. Funct. Ecol. 17: 562-567.

Hodkova M. \& Hodek I. 2004. Photoperiod, diapause and cold-hardiness. Eur. J. Entomol. 101: 445-458.

Hodkova M, Berková P. \& Zahradíčková H. 2002. Photoperiodic regulation of the phospholipid molecular species composition in thoracic muscles and fat body of Pyrrhocoris apterus (Heteroptera) via an endocrine gland, corpus allatum. J. Insect Physiol. 48: 1009-1019.

Holmstrup M., Sørensen L.I., Bindesbøl A. \& Hedlund K. 2007. Cold acclimation and lipid composition in the earthworm Dendrobaena octaedra. Comp. Biochem. Physiol. A. 157: 911-919.

Hsiao T.H. 1985. Eco-physiological and genetic aspects of geographic variations of the Colorado potato beetle. Research bulletin - Massachusetts Agricultural Experiment Station 704: 63-77.

Härtig C. 2008. Rapid identification of fatty acid methyl esters using a multidimensional gas chromatography-mass spectrometry database. J. Chromatogr. 1177: 159-169.

Iga M. \& Smagghe G. 2011. Relationship beween larval-pupal metamorphosis and transcript expression of insulin-like peptide and insulin receptor in Spodoptera littoralis. Peptides 32: 531-538. 
IPCC (2007) Climate Change 2007. The Physical Basis. Contribution of Working Group 1 to the Fourth Assessment of the Intergovernmental Panel on Climate Change, Geneva, Switzerland: IPCC Secretariat.

Jeschke J.M. \& Strayer D.L 2006. Determinants of vertebrate invasion success in Europe and North America. Global Change Biol. 12: 1608-1619.

Johnson C.G. 1967. International dispersal of insects and insect-borne viruses. Eur. J. Plant Pathol. 73: 21-43.

Kai Z., Huang J., Tobe S.S. \& Yang X. 2009. A potential insect growth regulator: synthesis and bioactivity of an allatostatin mimic. Peptides 30: 1249-1253.

Kauranen H, Tyukmaeva V \& Hoikkala A. 2013. Involvement of circadian oscillation(s) in the photoperiodic time measurumenet and the induction of reproductive diapause in a northern Drosophila species. J. Insect Physiol. 59: 662-666.

Kawecki T.J. \& Ebert D. 2004. Conceptual issues in local adaptation. Ecol. Lett. 7: 1225-1241.

Khan M.A. 1988. Brain-controlled synthesis of juvenile hormone in adult insects. Entomol. Exp. App. 46: 3-17.

Kirchner W. 1987. Behavioral and physiological adaptations to cold. In Nentwig, W. (ed) Ecophysiology of Spiders. Springer Verlag, Berlin.

Kivelä S.M., Välimäki P., Oksanen J., Kaitala A. \& Kaitala V. 2009. Seasonal clines of evolutionarily stable reproductive effort in insects. Am. Nat. 174: 526-36.

Kivelä S.M., Välimäki P., Carrasco D., Mäenpää M.I. \& Oksanen J. 2011. Latitudinal inset body size clines revisited: a critical evaluation of the sawtooth model. J. Anim. Ecol. 80: 1184-1195.

Klowden M.J. 2007. Physiological Systems in Insects. Academic Press, Burlington, MA.

Kolar C.S. \& Lodge D.M. 2001. Progress in invasion biology: predicting invaders. Trends Ecol. Evol. 16: 199-204.

Koopmanshap A.B., Oouchi H. \& de Kort C.A.D. 1989. Effects of a juvenile hormone analogue on the eggs, post-embryonic development, metamorphosis and diapause induction of the Colorado potato beetle, Leptinotarsa decemlineata. Entomol. Exp. Appl. 50: 255-263.

Koopmanschap B., Lammers H. \& de Kort S. 1992. Storage proteins are present in the hemolymph from larvae and adults of the Colorado potato beetle. Arch. Insect Biochem. Physiol. 20: 119-133.

Koopmanshap A.B., Lammers J.H.M. \& de Kort C.A.D. 1994. The structure of the gene encoding diapause protein 1 of the Colorado potato beetle (Leptinotarsa decemlineata). J. Insect Physiol. 41: 509-518.

Kostal V. 2006. Eco-physiological phases of insect diapause. J. Insect Physiol. 52: 113-127.

Kostal V. 2010. In: Denlinger, D.L. \& Lee, R. E. (eds.). Low temperature biology of insects. Cambridge University Press, Cambridge.

Kostal V. 2011. Insect photoperiodic calendar and circadian clock: independence, cooperation, or unity? J. Insect Physiol. 57: 538-556. 
Kostal V. \& Simek P. 1998. Changes in fatty acid composition of phospholipids and triacylglycerids after cold-acclimation of an aestivation insect prepupa. J. Comp. Physiol. B. 168: 453-460.

de Kort C.A.D. 1969. Hormones and the structural and biochemical properties of the flight muscles in the Colorado beetle. Med. Landb. Hogesch. Wag. 69: $1-63$.

de Kort C.A.D. 1990. Thirty-five years of diapause research with the Colorado potato beetle. Entomol. Exp. Appl. 56: 1-13.

de Kort C.A.D. 1996. Cosmic influences on the expression of a specific gene in the Colorado potato beetle: the diapause protein 1 gene. Arch. Insect Biochem. Physiol. 32: 567-573.

de Kort C.A.D., Bergot B.J. \& Schooley D.A. 1982. The nature and titre of juvenile hormone in the Colorado potato beetle, Leptinotarsa decemlineata. J. Insect Physiol. 28: 567-573.

Krebs H.A. \& Johnson W.A. 1937. The role of citric acid in intermediate metabolism in animal tissues. Enzymologia 4: 148-156.

Kuusik A., Hiesaar K., Metspalu L. \& Hermann P. 2001. The physiological characteristics of the perennial diapause in the Colorado potato beetles. Trans. Est. Agricult. Univ. 212: 161-166.

Lardies M.A., Baciagalupe L.D. \& Bozinovic F. 2004. Testing the metabolic cold adaptation hypothesis: an intraspecific latitudinal comparison in the common Woodlouse. Evol. Ecol. Res. 6: 567-578.

Leather S.R., Walters K.F.A. \& Bale J.S 1993. The ecology of insect overwintering. Cambridge University Press, Cambridge.

Lee R.E. 2010. In: Denlinger, D.L. \& Lee, R. E. (eds.). Low temperature biology of insects. Cambridge University Press, Cambridge.

Lee C.E. \& Petersen C.H. 2003. Effects of developmental acclimation on adult salinity tolerance in the freshwater-invading Eurytemora affinis. Physiol. Biochem. Zool. 76: 296-301.

Lee R.E., Costanzo J.P. \& Lee M.R. 1995. Reducing cold-hardiness of insect pests using ice nucleating active microbes. in Hallman G.J \& Denlinger D.L. (eds.) Temperature Sensitivity in Insects and application in integrated pest management. Westview Press, Colorado.

Lee C.E., Remfert J.L. \& Gelembiuk G.W. 2003. Evolution of physiological tolerance and performance during freshwater invasion events. Integr. Comp. Biol. 43: 439-449.

Lefevere K.S. \& de Kort C.A.D. 1989. Adult diapause in the Colorado potato beetle, Leptinotarsa decemlineata: effects of external factors on maintenance, termination and post-diapause development. Physiol. Entomol. 14: 299-308.

Lefevere K.S., Koopmanschap A.B. \& de Kort C.A.D. 1989. Changes in the concentrations of metabolites in heamolymph during and after diapause in female Colorado potato beetle, Leptinotarsa decemlineata. J. Insect Physiol. 35: 121-128.

Lindquist S. 1986. The heat-shock response. Annu. Rev. Biochem. 55: 1151-1191.

Logan P.A., Casagrande R.A., Faubert H.H. \& Drummond F.A. 1985. Temperature-dependent development and feeding of immature Colorado 
potato beetles, Leptinotarsa decemlineata Say (Coleoptera: Chrysomelidae). Environ. Entomol. 14: 275-283.

de Loof A. \& Lagasse A. 1970. Juvenile hormone and the ultrastructural properties of the fat body of the adult Colorado beetle, Leptinotarsa decemlineata Say. Zeitschrift fur Mikroskopisch-Anatomische Forschung 106: 439-450.

Lyytinen A., Lindström L. \& Mappes J. 2008. Genetic variation in growth and development time under two selection regimes in Leptinotarsa decemlineata. Entomol. Exp. Appl. 127: 157-167.

Lyytinen A., Mappes J. \& Lindström L. 2012. Variation in Hsp70 levels after cold shock: signs of evolutionary responses to thermal selection among Leptinotarsa decemlineata populations. PLoS ONE 7: e31446.

Lyytinen A., Boman S., Grapputo A., Lindström L. \& Mappes J. 2009. Cold tolerance during larval development: effects on the thermal distribution limits of Leptinotarsa decemlineata. Entomol. Exp. Appl. 133: 92-99.

MacRae T.H. 2010. Gene expression, metabolic regulation and stress tolerance during diapause. Cell. Mol. Life Sci. 67: 2405-2424.

Matthews P.G.D. \& White C.R. 2011. Regulation of gas exchange and heamolymph $\mathrm{pH}$ in the cockroach Nauphoeta cinerea. J. Exp. Biol. 214: 30623073.

Milner M., Kung K.J.S., Wyman J.A., Feldman J. \& Nordheim E. 1992. Enhancing overwintering mortality of Colorado potato beetle (Coleoptera: Chrysomelidae) by manipulation the temperature of its diapause habitat. J. Econ. Entomol. 85: 1701-1708.

Mousseau T.A. 1997. Ectotherms follow the converse to Bergmann's rule. Evolution 51: 630-632.

Mousseau T.A. \& Dingle H. 1991. Maternal effects in insect life histories. Annu. Rev. Entomol. 36: 511-534.

Murdoch W.W. 1966. Population stability and life history phenomena. Am. Nat. 100: 45-51.

Nelson R.J., Denlinger D.L. \& Somers D.E. (eds.) 2010. Photoperiodism, the biological calendar. Oxford University Press, Oxford.

Newman H.A.I., Gordon E.A., Heggen D.W. \& Keller M.D. 1972. Rapid extraction of triglycerides from human adipose tissue. Clin. Chem. 18: 290292.

Nijhout H.F. 1994. Insect hormones. Princeton University Press, New Jersey.

Nijhout H.F., Roff D.A. \& Davidowitz G. 2010. Conflicting processes in the evolution of body size and development time. Phil. Trans. R. Soc. Lond. B. 365: 567-75.

Oostra V. 2013 Hormonal and transcriptional mechanisms underlying developmental plasticity of life histories in a seasonal butterfly. PhD Thesis, Faculty of Science, Leiden University.

Oostra V., de Jong M.A., Invergo B.M., Kesbeke F., Brakefield P.M. \& Zwaan B.J. 2010. Translating environmental gradients into discontinuous reaction norms via hormone signalling in a polyphenic butterfly. Proc. R. Soc. B. 278: 789-797. 
Phillips B.L. \& Suarez A.V. 2012. The role of behavioural variation in the invasion of new areas. in Candolin U. \& Wong B.M (eds.): Behavioural responses to a changing world: mechanisms and consequences. Oxford University Press, Oxford.

Piiroinen S., Ketola T., Lyytinen A. \& Lindström L. 2011. Energy use, diapause behaviour and northern range expansion potential in the invasive Colorado potato beetle. Funct. Ecol. 25: 527-536.

Ragland G.J, Denlinger D.L. \& Hahn D.A. 2010. Mechanisms of suspended animation are revealed by transcript profiling of diapause in the flesh fly. Proc. Nat. Acad. Sci. USA. 107: 14909-14914.

Randall D., Burggren W. \& French K. (eds.) 2002. Animal physiology. Freeman and Company, New York.

Reece J.B., Urry L.A., Cain M.L., Wasserman S.A., Minorsky P.V. \& Jackson R.B. 2011. Biology. Pearson Benjamin Cummings, San Fransisco.

Reichard S.H. \& Hamilton C.W. 1997. Predicting invasions of woody plants introduced into North America. Conserv. Biol. 11: 193-203.

Revuelta L., Ortego F., Díaz-Ruíz J.R., Castaear P., Tenllado F. \& HernándezCrespo P. 2011. Contribution of Ldace1 gene to acetylcholinesterase activity in Colorado potato beetle. Insect Biochem. Molec. Biol. 41: 795-803.

Riley C.V. 1877. Ninth annual report on the noxious, beneficial, and other insects of the state of Missouri. Regand and Carter, Jefferson City, MO.

Rinehart J.P., Li A., Yocum G.D., Robich R.M., Hayward S.A.L. \& Denlinger D.L. 2007. Up-regulation of heat shock proteins is essential for cold survival during insect diapause. Proc. Nat. Acad. Sci. USA. 104: 1113011137.

Roberts S.B. \& Rosenberg I. 2006. Nutrition and aging: changes in the regulation of energy metabolism with aging. Physiol. Rev. 86: 651-667.

Roff D.A. 1980. Optimizing development time in a seasonal environment: the "ups and downs" of clinal variation. Oecologia 45: 202-208.

Roff D.A. 1983. Phenological adaptation in a seasonal environment: a theoretical perspective. In Brown, V.K. \& Hodek, I. (eds.), Diapause and life cycle strategies in insects. Dr. W. Junk Publishers, The Hague.

Roff D.A. 1992. The evolution of life histories. Chapman \& Hall, New York, NY.

Saikkonen K., Taulavuori K., Hyvönen T., Gundel P.E., Hamilton C.E., Vänninen I., Nissinen A. \& Helander M. 2012. Climate change-driven species' range shifts filtered by photoperiodism. Nature Clim. Change 2: 239-242.

Sakai A.K., Allendorf F.W., Holt J.S., Lodge D.M., Mologsky J., With K.A., Baughman S., Cabin R.J., Cohen J.E., Ellstrand N.C., McCauley D.E., O'Neil P., Parker I.M., Thomspon J.N. \& Weller S.G. 2001. The population biology of invasive species. Annu. Rev. Ecol. Syst. 32: 305-332.

Salt R.W. 1961. Principles of insect cold-hardiness. Annu. Rev. Entomol. 6: 55-74. Saunders D.S. 2002. Insect clocks. Elsevier Science.

Sax D.F., Stachowicz J.J., \& Gaines S.D. (eds.) 2005. Species invasions: insights into ecology, evolution and biogeography. Sinauer, Sunderland, MA. 
Say T. 1824. Descriptions of coloepterous insects collected in the late expedition to the Rocky Mountains, performed by order of Mr. Calhoun, Secretary of War, under the command of Major Long. J. Acad. Nat. Sci. Phila. 3: 303462.

Schmidt P.S. 2011. Evolution and mechanisms of insect reproductive diapause: a plastic and pleiotropic life history syndrome. In: Flatt T \& Heyland A. Mechanisms of life history evolution. Oxford University Press, New York.

Senyanake D.G., Radcliffe E.B. \& Holliday N.J. 2000. Oviposition and diapause behavior in Colorado potato beetle (Coleoptera: Chrysomelidae) populations from east central Minnesota and the valley of the red river of the north. Environ. Entomol. 29: 1123-1132.

Sim C. \& Denlinger D.L. 2008. Insulin signaling and FOXO regulate the overwintering diapause of the mosquito Culex pipiens. Proc. Nat. Acad. Sci. USA. 105: 6777-6781.

Sim C. \& Denlinger D.L. 2013. Juvenile hormone III suppresses forkhead of transcription factor in the fat body and reduces fat accumulation in the diapausing mosquito, Culex pipiens. Insect Mol. Biol. 22: 1-11.

Sinensky M. 1974. Homeoviscous adaptation - A homeostatic process that regulates the viscosity of membrane lipids in Escherichia coli. Proc. Nat. Acad. Sci. USA. 71: 522-525.

Somme L. 1999. The physiology of cold hardiness in terrestrial arthropods. Eur. J. Entomol. 96: 1-10.

Stearns S.C. 1992. The evolution of life histories. Oxford University Press, London.

Stegwee D., Kimmel E.C., De Boer J.A. \& Henstra S. 1963. Hormonal control of Reversible Degeneration of Flight Muscle in the Colorado Potato Beetle, Leptinotarsa decemlineata Say (Coleoptera). J. Cell Biol. 19: 519-527.

Szentesi A. 1985. Behavioural aspects of female guarding and inter-male conflict in the Colorado potato beetle. In: Ferro D.N. \& Voss R.H (eds.) Proceedings, Symposium on the Colorado potato beetle. XVII th International Congress of Entomology, Research Bulletin 704: 127-137.

Taipale S., Jones R.I. \& Tiirola M., 2009. Vertical diversity of bacteria in an oxygen-stratified humic lake, evaluated using DNA and phospholipid analyses. Aquat. Microb. Ecol. 55: 1-16.

Tatar M, Kopelman A, Epsetin D, Tu MP, Yin CM \& Garofalo RS 2001. A mutant Drosophila insulin receptor homolog that extends life-span and impairs neuroendocrine function. Science 292: 107-110.

Tauber M.J. \& Tauber C.A. 2002. Prolonged dormancy in Leptinotarsa decemlineata (Coleoptera: Chrysomelidae): a ten-year field study with implications for crop rotation. Environ. Entomol. 31: 499-504.

Tauber M.J., Tauber C.A. \& Masaki S. 1986. Seasonal adaptations of insects. Oxford University Press, New York.

Tauber M.J., Tauber C.A., Obrycki J.J., Gollands B. \& Wright R.J. 1988. Geographical variation in responses to photoperiod and temperature by Leptinotarsa decemlineata (Coleoptera: Chrysomelidae) during and after 
dormancy. University of Nebraska, Faculty Publications: Department of Entomology, Paper 100.

Terblanche J.S. \& Anderson B. 2010. Variation of foraging rate and wing loading, but not resting metabolic rate scaling, of insect pollinators. Naturwissenschaften 97: 775-780.

Thebaud C., Finzi A.C. Debussche M. \& Escarre J. 1996. Assessing why two intriduced Conyza differ in their ability to invade Mediterranean old fields. Ecology 77: 791-804.

Thirgood S., Mosser A., Tham S., Hopcraft G., Mwangomo E., Mlengeya T., Kilewo M., Fryxell J. Sinclair A.R.E. \& Borner M. 2004. Can parks frotect migratory ungulates? The case of the Serengeti wildebeest. Anim. Conservat. 7: 113-120.

Tower W.L. 1906. Evolution in chrysomelid beetles. Carnagie Institution, Washington.

Urbanski J., Mogi M., O’Donnell D., DeCotiis M., Toma T. \& Armbruster P. 2012. Rapid adaptive evolution of photoperiodic response during invasion and range expansion across a climatic gradient. Am. Nat. 179: 490-500.

Ushatinskaya R.S. 1956. Physiologische Untersuchungen über die Diapause der Insekten. Bericht Über die Hundertjahrfeier der Deutschen Entomologisches Gesellschaft Berlin 251-263.

Valosaari K-R., Aikio S. \& Kaitala V. 2008. Spatial simulation model to predict the Colorado potato beetle invasion under different management strategies. Ann. Zool. Fennici 45: 1-14.

Vermunt A.M.W., Vermeesch A.M.G. \& de Kort C.A.D. 1997. Purification and characterization of juvenile hormone esterase from hemolymph of the Colorado potato beetle. Arch. Insect Biochem. Physiol. 35: 261-277.

Vermunt A.M.W., Koopmanschap A.B., Vlak J.M. \& de Kort C.A.D. 1999. Expression of the juvenile hormone esterase gene in the Colorado potato beetle, Leptinotarsa decemlineata: photoperiodic and juvenile hormone analog response. J. Insect Physiol. 45: 135-142.

van Voorhies W.A. 1996. Bergmann size clines: A simple explanation for their occurrence in ectotherms. Evolution 50: 1259-1264.

Voss R.H. \& Ferro D.N. 1990. Phenology of flight and walking by Colorado potato beetle (Coleoptera: Chrysomelidae) adults in western Massachusetts. Environ. Entomol. 19: 117-122.

Walsh B.D. 1865. The new potato-bug, and its natural history. The Practical Entomologist 1: 1-4.

de Wilde J., Duintjer C.S. \& Mook L. 1959. Physiology of diapause in the adult Colorado potato beetle (Leptinotarsa decemlineata Say) - I the photoperiod as a controlling factor. J. Insect Physiol. 3: 75-85.

Williams C.M., Thomas R.H., MacMillan H.A., Marshall K.E. \& Sinclair B.J., 2011. Triacylglyceride measurement in small quantities of homogenised insect tissue: comparisons and caveats. J. Insect Physiol. 57: 1602-1613.

Williams K.D., Busto M., Suster M.L., So A.K.C., Ben-Shahar Y., Leevers S.J. \& Sokolowksi M.B. 2006. Natural variation in Drosophila melanogaster 
diapause due to the insulin-regulated PI3-kinase. Proc. Nat. Acad. Sci. USA. 103: 15911-15915.

Williamson M. \& Fitter A. 1996. The varying success of invaders. Ecology 77: 1661-1666.

Willmer P., Stone G. \& Johnston I. (eds.) 2000. Environmental physiology of animals. Blackwell Science, Oxford.

Winkler G., Dodson J.J. \& Lee, C.E. 2008. Heterogeneity within the native range: population genetic analyses of sympatric invasive and noninvasive clades of the freshwater invading copepod Eurytemora affinis. Mol. Ecol. 17: 415430.

Worland M.R., Block W. \& Grubor-Lajsic G. 2000. Survival of Heleomyza borealis (Diptera, Heleomyzidae) larvae down to $-60^{\circ} \mathrm{C}$. Physiol. Entomol. 25: 1-5.

Wright T.F., Eberhard J.R., Hobson E.A., Avery M.L. \& Russello M.A. 2010. Behavioral flexibility and species invasions: the adaptive flexibility hypothesis. Ethol. Ecol. Evol. 22: 393-404.

Yocum G.D. 2001. Differential expression of two HSP70 transcripts in response to cold shock, thermoperiod, and adult diapause in the Colorado potato beetle. J. Insect Physiol. 47: 1139-1145.

Yocum G.D. 2003. Isolation and characterization of three diapause-associated transcripts from the Colorado potato beetle, Leptinotarsa decemlineata. J. Insect Physiol. 49: 161-169.

Yocum G.D., Rinehart J.P. \& Larson M.L. 2011. Monitoring diapause development in the Colorado potato beetle, Leptinotarsa decemlineata, under field conditions using molecular biomarkers. J. Insect Physiol. 57: 645-652.

Yoshida T., Goka K., Ishihama F., Ishihara M. \& Kudo S. 2007. Biological invasion as a natural experiment of the evolutionary processes: introduction of the special feature. Ecol. Res. 22: 849-854.

Zachariassen K.E., Li N.G., Laugsand A.E., Kristiansen E. \& Pedersen S.A. 2008. Is the strategy for cold hardiness in insects determined by their water balance? A study on two closely related families of beetles: Cerambycidae and Chrysomelidae. J. Comp. Physiol. B. 178: 977-984.

Zera A.J. 2007. Endocrine analysis in evolutionary-developmental studies of insect polymorphism: hormone manipulation versus direct measurement of hormonal regulators. Evol. Dev. 9: 499-513. 